\title{
Marine Transcriptomics Analysis for the Identification of New Antimicrobial Peptides
}

\author{
Baptiste Houyvet ${ }^{1,2,3}$, Yolande Bouchon-Navaro ${ }^{1,4}$, Claude Bouchon ${ }^{1,4}$, Erwan Corre 5 \\ and Céline Zatylny-Gaudin $1,2, *$ (1)
}

1 Biologie des Organismes et Ecosystèmes Aquatiques (BOREA) Muséum National d'Histoire Naturelle, Sorbonne Université, Université de Caen-Normandie, Université des Antilles, CNRS-8067, IRD 207, 75231 Paris, France; baptiste.houyvet@satmar.fr (B.H.); yolandebouchon1@gmail.com (Y.B.-N.); claudebouchon1@gmail.com (C.B.)

2 BOREA, Normandie University, University of Caen-Normandy, Esplanade de la Paix, CEDEX, 14032 Caen, France

3 SATMAR, Société ATlantique de MARiculture, Research and Development Department, 50760 Gatteville, France

4 Laboratoire d'Excellence “CORAIL”, Université des Antilles, Campus de Fouillole, BP 592, Pointe-à-Pitre, 97159 Guadeloupe, France

5 Plateforme ABiMS, Station Biologique de Roscoff, CNRS-Sorbonne Université, 29688 Roscoff, France; corre@sb-roscoff.fr

* Correspondence: celine.gaudin@unicaen.fr

Citation: Houyvet, B.;

Bouchon-Navaro, Y.; Bouchon, C.; Corre, E.; Zatylny-Gaudin, C. Marine Transcriptomics Analysis for the Identification of New Antimicrobial Peptides. Mar. Drugs 2021, 19, 490. https://doi.org/10.3390/md19090490

Academic Editor: Marc Diederich

Received: 3 August 2021

Accepted: 23 August 2021

Published: 28 August 2021

Publisher's Note: MDPI stays neutral with regard to jurisdictional claims in published maps and institutional affiliations.

\begin{abstract}
Antimicrobial peptides (AMPs) participate in the immune system to avoid infection, are present in all living organisms and can be used as drugs. Fish express numerous AMP families including defensins, cathelicidins, liver-expressed antimicrobial peptides (LEAPs), histone-derived peptides, and piscidins (a fish-specific AMP family). The present study demonstrates for the first time the occurrence of several AMPs in lionfish (Pterois volitans). Using the lionfish transcriptome, we identified four transcript sequences encoding cysteine-rich AMPs and two new transcripts encoding piscidin-like peptides. These AMPs are described for the first time in a species of the Scorpaenidae family. A functional approach on new pteroicidins was carried out to determine antimicrobial sequences and potential uses, with a view to using some of these AMPs for human health or in aquaculture.
\end{abstract}

Keywords: venomous fish; lionfish; antimicrobial peptides; transcriptomic

\section{Introduction}

Antimicrobial peptides (AMPs) are the major cornerstone of the innate immune system that protects the host against infection. Their diversity is huge: they are found in all living organisms ranging from microorganisms to pluricellular organisms like plants and animals. They also differ in structure and activity [1-4]. Fish are a major component of the aquatic fauna. They live in a microbe-rich environment and are permanently surrounded by aquatic pathogens. Their skin has a key function in physical and physiological protection as a first defense barrier where AMPs play an antagonistic role against invasive pathogens. Several AMPs were recently identified in fish, including liver-expressed antimicrobial peptides (hepcidins and LEAP-2), defensins, cathelicidins, histone-derived peptides, and a fish-specific family called the piscidins [5].

Among the AMPs characterized so far in fish, some of them are also found in mammals, in particular cysteine-rich peptides that make up a large AMP group including LEAPs, $\beta$-defensins, NK-lysins and cathelicidins. Concerning fish LEAPs, the first hepcidin was described in the gills of hybrid striped bass after bacterial challenge [6]. Mature fish hepcidins can have six or eight cysteine residues, as observed in winter flounder (Pseudopleuronectes americanus) and Atlantic salmon (Salmo salar) hepcidin-like peptides [7]. 
Besides antimicrobial activity against fungi and both Gram-positive and Gram-negative bacteria [8,9], hepcidin can act as an iron-regulatory hormone [10]. A second cysteine-rich antimicrobial peptide derived from liver or LEAP-2 was identified in fish, with four highly conserved cysteine residues. The first two genes of LEAP-2 were identified in rainbow trout (Oncorhynchus mykiss); they displayed constitutive expression in the liver and inducible expression in the intestine and skin [11]. LEAP-2 is an important immune factor involved in the immune response against pathogens in fish [11-13]. LEAP-1 and -2 derived from Antarctic notothenioid (Dissostichus mawson) and eelpout (Lycodichthys Dearborni) revealed bactericidal activity against Gram-positive as well as Gram-negative bacteria, particularly at low temperatures [14]. Defensins have a conserved compact structure displaying a set of cationic loops and they have multiple innate immune functions [15]. Vertebrate defensins have a characteristic $\beta$-sheet-rich fold involving six cysteines connected by disulfide bonds. The family is subdivided into $\alpha$-defensins and $\beta$-defensins based on the pairing of cysteines and the length of the amino acid sequences between the cysteines [16]. Only $\beta$-defensinlike structures have been observed in fish to date [17-19]. The first fish defensins were discovered by Zou et al. [18] who identified seven $\beta$-defensins in the three fish species: zebrafish (Danio rerio), fugu (Takifugu rubripes) and tetraodon (Tetraodon nigroviridis). The biological activity of fish $\beta$-defensins has been studied and demonstrated: antimicrobial activity against Gram-negative and Gram-positive bacteria, activity against fish-specific viruses, and chemotactic capacity $[17,20,21]$. Antimicrobial activity has also been observed for NK-lysins derived from fish [22,23]. NK-lysin was initially identified as an antimicrobial peptide from porcine natural killer cells and cytotoxic T lymphocytes [24]. In fish, several NK-lysins have been identified, with a conserved saposin domain including four cysteines and at the origin of their antimicrobial activity [25].

Most of the cysteine-rich peptides of fish display important sequence homologies, except cathelicidins which display sequence divergences. Cathelicidin precursors contain a signal peptide, a conserved cathelin-like domain with four cysteines, and a variable C-terminal antimicrobial domain with or without cysteines [26-28]. Cathelicidins have been identified in several fish; the first peptides were identified in Atlantic hagfish (Myxine glutinosa) [29], rainbow trout (O. mykiss) and Atlantic salmon (S. salar) [30]. The antimicrobial activity of fish cathelicidins is variable. For example, codCATH-a cathelicidin from Atlantic cod (Gadus morhua) - is highly active against Gram-negative bacteria and fungi but less active on Gram-positive bacteria [31]. Fish can have several cathelicidin genes with different expression profiles following bacterial challenge. In rainbow trout, the rtCATH-2 gene displays a high basal expression level whereas rtCATH_1 is induced upon bacterial challenge [32]. In ayu (Plecoglossus altivelis), expression of the cathelicidin gene has been detected in numerous tissues including gill, liver, spleen and intestine, with a time-dependent induction after challenge [33]. Other AMPs that do not contain any cysteine and with little sequence homology have been identified in fish e.g., piscidins [34]. Piscidins possess 18 to 46 amino acid residues; they are amphipathic $\alpha$-helical peptides [35,36]. The first piscidin to be identified was pleurocidin, a 25-residue peptide isolated and characterized from Pleuronectes americanus [37]. Piscidins are present in a wide range of teleosts, particularly in the order Perciformes [38]. They are localized in gill, skin, intestine, head-kidney and spleen tissues. They are an important component of fish immune defense against pathogens [37], and their antimicrobial activity is strong against a range of microorganisms and maintained under high salt concentrations [39].

Antimicrobial peptides have been studied in many non-venomous teleosts [5]. Only one study has been carried out on a venomous teleost-lionfish (Pterois volitans) — so far, and has led to the identification of pteroicidin $\alpha$, a piscidin-like-peptide [40]. Lionfish recently invaded the western North Atlantic region, and more particularly the Caribbean Sea [41]. This venomous species is native from the Indo-Pacific Ocean. It was accidentally released from a public aquarium in Florida in 1992 and since then has colonized most of the coasts of the Gulf of Mexico and the Caribbean Sea. This aggressive predator represents a major threat to local biodiversity and local coral reef ecology [42,43]. The 
success of its initial invasion was probably due to the lack of adapted predators, parasites and microbial pathogens. The situation has evolved however, with the emergence of new predators [44-47], parasites [48-50], and diseases [51]. This has resulted in a drop in $P$. volitans abundance in the Caribbean area [52] (personal observations). However, the presence of pathogenic bacteria in lionfish in the natural environment or in captivity in aquaria has not been described to date. The present study focuses on the diversity of antimicrobial peptides present in lionfish. We associated a transcriptomic approach carried out from annotated and non-annotated transcripts and a functional approach to identify new antibacterial peptides.

\section{Results and Discussion}

\subsection{In Silico Analysis of the Transcriptome}

The analysis of the transcriptome of the venomous spines and pelvic fins of Pterois volitans yielded 47,421 unique transcript sequences. Annotation of the protein sequences using the Uniprot_Swissprot and NCBI NR databases yielded transcripts encoding skin proteins like collagen and keratin, and previously studied venom proteins like toxin $\alpha$, toxin $\beta$ and hyaluronidase $[53,54]$. Other transcripts corresponding to immune factors were also identified, especially four full-length transcripts encoding cysteine-rich antimicrobial peptides: one $\beta$-defensin, two peptides related to liver-expressed antimicrobial peptides (hepcidin and LEAP-2), and one NK-lysin. Alignment of lionfish $\beta$-defensin with $\beta$-defensins of other fish is presented in Figure 1A. The precursor of defensins is organized more simply than the precursors of other cysteine-rich peptides, with a signal peptide followed by 42 -amino-acid (AA) $\beta$-defensin. The sequence of $\beta$-defensin is well conserved among fish, with amino acid identity $>95 \%$ with $\beta$-defensins of puffer fish (Tetraodon nigriviridis), Nile tilapia (Oreochromis niloticus) or rainbow trout (O. mykiss). The positions of the six cysteines are conserved; only two amino acid residues differ between the $\beta$-defensin sequences of P. volitans, T. nigriviridis and O. niloticus. Lionfish $\beta$-defensin possesses characteristic features of cationic peptides, with a net charge of 1.7, a molecular weight of $4495.39 \mathrm{Da}$, and an isoelectric point of 8.35. The occurrence of $\beta$-defensin in lionfish pelvic fins was confirmed by mass spectrometry analysis in the alkylated and digested sample using NanoLC-ESI-LTQ-Orbitrap. We detected two trypsic peptides: KVCLPTELFFGPLGCGK and VCLPTELFFGPLGCGK.

Our transcriptomic analysis also identified two precursors encoding peptides related to liver-expressed antimicrobial peptides. The first one was Pv-hepcidin. Alignment of the predicted amino acid sequence of $P v$-hepcidin with hepcidins from other fish is shown in Figure 1B. The highest level of amino acid identity was observed with hepcidins of medaka (Oryzias melastigma) (78.99\%) and rainbow trout (O. mykiss) (77.78\%). The predicted prepropeptide of $\mathrm{Pv}$-hepcidin contained a 24-AA signal peptide, a 40-AA prodomain, and a 26-AA mature peptide. Sequence variability was mainly observed in the signal peptide and prodomain regions. Between the prodomain region and hepcidin stood a conserved $R X(K / R) R$ motif of propeptide convertase that releases the mature peptide [55]. The predicted mature hepcidin of lionfish contained 8 cysteines with $\mathrm{N}$ - and C-terminal sequences conserved with other fish hepcidins. With a calculated molecular weight (MW) of $3001.58 \mathrm{Da}$, a pI of 8.76 , a hydrophobic ratio of $50 \%$ and a total net charge of 4 , lionfish hepcidin exhibited antimicrobial characteristics. The arrangement of the eight conserved cysteines in hepcidins conferred them the tridimensional structure essential for antimicrobial activity, as described for zebrafish hepcidin [56]. 
A

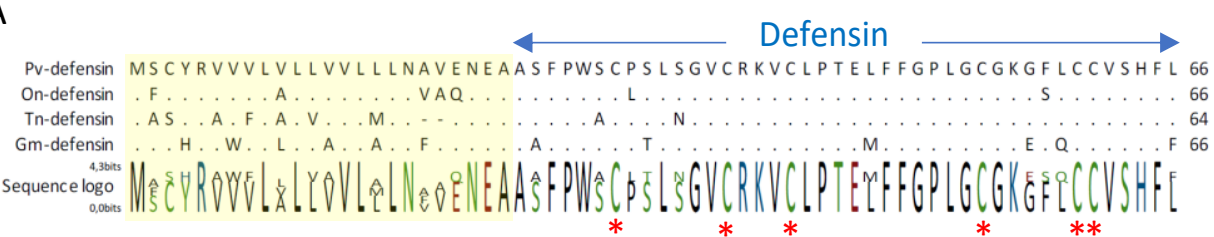

B

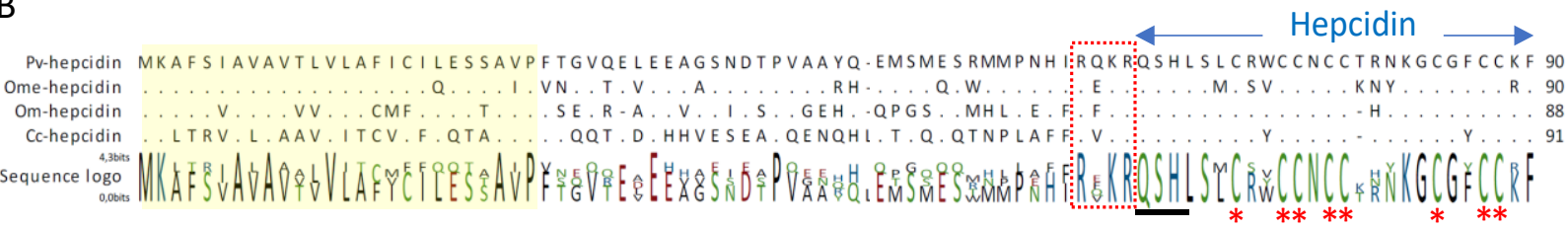

C

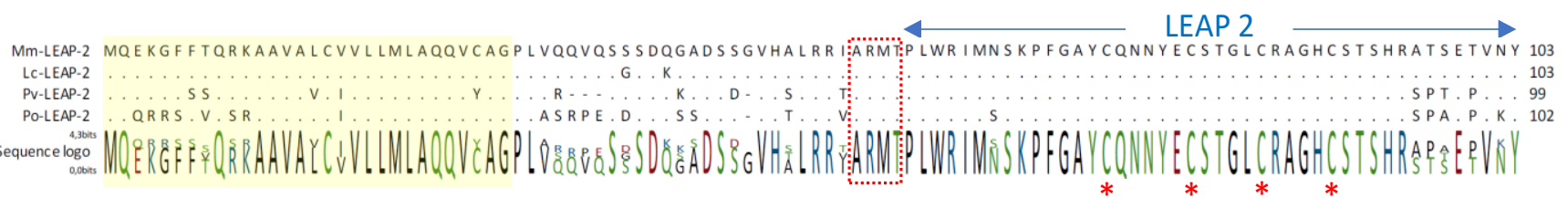

D

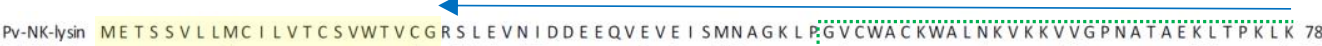

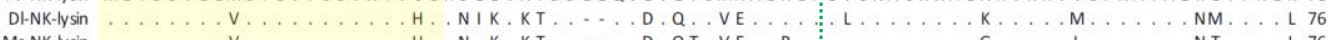

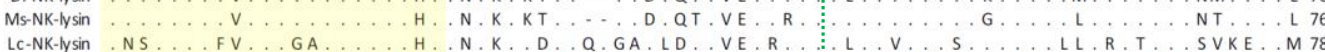

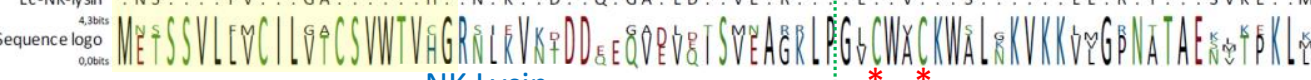

NK Lysin

PV-NK-IYSin SICNQIGLLKSLCYKFVKAHLAELIEELSTTDDVKT ICINTGACKRKELSDLLFYPSKEESSVEI I SDVVIMGNN 153

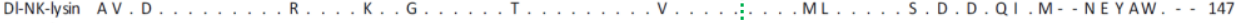

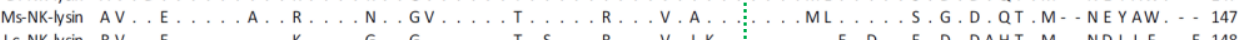

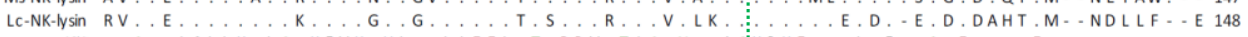

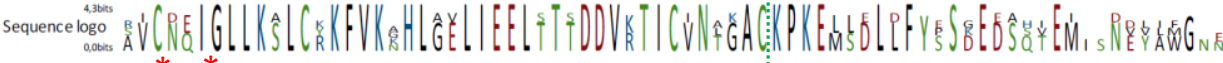

Cicidin-B MRCAMMFLVLTLVILMAEPGDCFFKRLKNAFKSARQAWRDYKTNAAMQKRAPGNG............PQGYPNQAQPP - PYKR 70

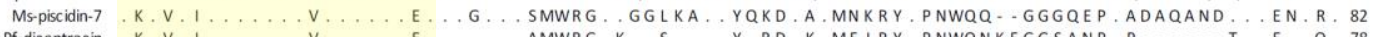

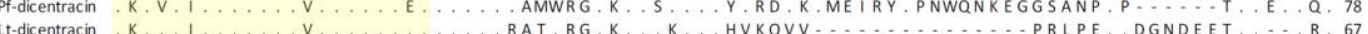

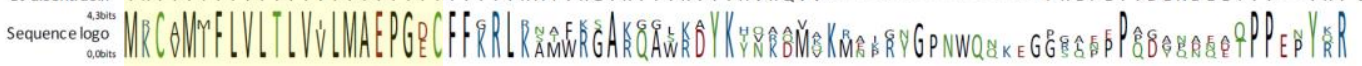

F

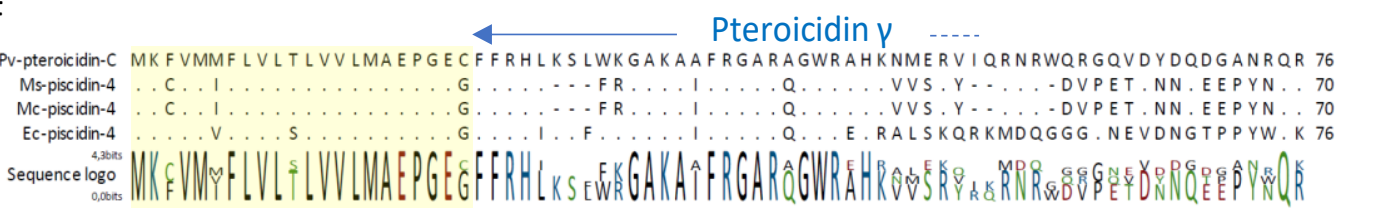

Figure 1. Sequence alignment of antimicrobial peptide precursors identified in lionfish. (A) Alignment of Pterois volitans Pv-defensin with Tetraodon nigroviridis Tn-defensin (CAJ57644.1), Oreochromis niloticus On-defensin (AGW83444.1), and Gadus morhua Gm-defensin (AEB69787.1). (B) Alignment of P. volitans Pv-hepcidin with Oryzias melastigma Ome-hepcidin (AEG78327.1), Oncorhynchus mykiss Om-hepcidin (ADU85830.1) and Cyprinus carpio Cc-hepcidin (AFY23859.1). Dotted red boxes, $\mathrm{RX}(\mathrm{K} / \mathrm{R}) \mathrm{R}$ motif for cleavage of the mature hepcidin peptide; underlining, QSHL motif. (C) Alignment of $P$. volitans Pv-LEAP-2 (liver-expressed antimicrobial peptide 2) with Miichthys miiuy Mm-LEAP-2 (AHN13905.1), Larimichthys crocea Lc-LEAP-2 (AFC90192.1), and Paralichthys olivaceus Po-LEAP-2 (ACB97648.1). Dotted red boxes, RXXR motif for the cleavage of the mature LEAP-2 peptide. (D) Alignment of P. volitans Pv-NK-lysin with P. olivaceus Po-NK-lysin (AU260449.1) and L. crocea Lc-NK-lysin (AIL25791.1). Dotted blue box, saposin B domain; red asterisks, cysteines. (E) Alignment of $P$. volitans Pv-pteroicidin-B with Morone saxatilis Ms-piscidin-7 (KX231322.1), Perca flavescens Pf-dicentracin (XP_028460572.1), Liparis tanakae Lt-dicentracin (TNN22976.1). (F) Alignment of P. volitans Pv-pteroicidin-C with M. saxatilis Ms-piscidin4 (APQ32049.1), hybrid [M. chrysops $x$ M. saxatilis] Mh-piscidin-4 (ADP37959.1), and Epinephelus coioides Ec-piscidin 4 (AKA60777.2). The sequence logo summarizes the consensus sequence and amino acid variations with fish sequences. Yellow, signal peptide; Blue arrow, antimicrobial sequence.

Lionfish hepcidin also possessed the N-terminal sequence QSHL that is essential for iron homeostasis and controls ferroportin internalization and degradation, as observed for 
zebrafish hepcidin [57]. Lionfish hepcidin, like other vertebrate hepcidins, potentially plays a dual function in iron regulation and host defense. We only found one transcript encoding hepcidin in lionfish, but other genes may be expressed in liver or other tissues, as in several teleosts [7,57-60]. We also identified a second liver-expressed AMP in lionfish pelvic fin and venomous spines, namely liver-expressed antimicrobial-related peptide 2-Pv-LEAP-2. Sequence alignment of Pv-LEAP-2 with other LEAP-2 precursors of teleosts highlighted the same conformation, with a signal peptide, a prodomain and a mature peptide (Figure 1C). The conserved RXXR motif for propeptide convertases was located before the cleavage site separating the prodomain from the mature peptide, as observed in other LEAP-2 transcripts [13]. LEAP-2 sequences mainly varied in the prodomain region, whereas the signal peptide and mature peptide sequences were well conserved. The mature peptide $P v-$ LEAP-2 shared high amino acid identity $(>90 \%)$ with other fish LEAP-2-related peptides. $P v$-LEAP-2, like other selected fish LEAP-2s, is a 46-AA peptide with four conserved cysteine residues, a net charge of 2 , a hydrophobic ratio around $30 \%$, and an isoelectric point $\sim 8.5$. While disulfide bonds appear necessary for antimicrobial activity of hepcidins, they do not seem necessary for antimicrobial activity of LEAPs, as suggested for human LEAP-2 [61]. No data are available about the structure-bioactivity relationships in fish. Few antimicrobial activities of fish LEAP-2 have been described. Lionfish LEAP-2 probably has the same activity as Mm-LEAP-2, which only differs by four amino acid residues in the C-terminal end [13].

The last cysteine-rich AMP we identified in lionfish was an NK-lysin-related-peptide. The $P v$-NK-lysin-RP precursor consisted of 153 AA residues. In silico analysis showed that $P v$-NK-lysin-RP contained a signal peptide sequence (residues 1-22) and a saposin B domain (residues 48-122) well conserved among fish NK-lysins (Figure 1D). Structure prediction of $P v$-NK-lysin-RP indicated five $\alpha$-helices spaced out by three loops in the protein molecule, as demonstrated for the structure of porcine NK-lysin and human granulysin, two members of the saposin-like protein family (SAPLIP) [62-64]. NK lysins or derived peptides have been showed to display antimicrobial activity. The saposin B domains of three Channel catfish NK-lysins had an antimicrobial effect on Escherichia coli and Staphylococus aureus [25]. Moreover, antimicrobial activity was observed for sequences corresponding to the cationic core region of the NK lysin saposin domain of Larimichthys crocea and Paralichthys olivaceus [22,23]. The saposin domain with its six cysteines is well conserved among NK-lysins of fish and lionfish (Figure 1D) and suggests a potential function in the immune response and probable antimicrobial activity.

Only 26\% of transcriptome was annotated in Uniprot-Swissprot, 22\% in Pfam, leaving more than 34,000 sequences unannotated. To identify other antimicrobial peptides already identified in fish like cathelicidins or other piscicidins but not annotated after similarity search in lionfish transcriptome, we used the software program Peptraq [65]. This in silico search using lionfish transcriptome data identified two new piscidin precursors-pteroicidins B and C. Pteroicidin A had already been identified in a previous study [40]. The precursors of piscidins have very few conserved motifs at the level of the antimicrobial peptide, but their signal peptides are highly similar (Appendix A, Figure A1). Using the FLVL and MAEPG motifs in Peptraq software, two new piscidin precursors were extracted from the database. This confirmed the high sequence homology at the level of the signal peptide. This in silico search also revealed the limitations of BLAST annotation and the usefulness of a software program like Peptraq for targeted searches. It can be a quick way to identify new AMPs in other closely related species, and in particular new piscidins, provided that genomic or transcriptomic databases are available. The study of pteroicidins B and C showed that the sequence corresponding to the signal peptide shared at least $77 \%$ identity with those of the other piscidins shown in Figure 1E and F. Pteroicidin C had a high \% identity $(>55 \%$ ) with piscidin- 4 of white bass (Morone chrysops), hybrid striped bass (Morone chrysops $x$ Morone saxatilis), striped bass (Morone saxatilis), and orange-spotted grouper (Epinephelus coides) (Figure 1F), whereas pteroicidin B seemed to be closer to piscidin-7 of Morone saxatilis with $48 \%$ identity (Figure 1E). No mature forms of piscidin-7 precursors 
close to pteroicidin were characterized, and no antibacterial activity was demonstrated. Concerning piscidin-4, only one mature peptide was identified from hybrid striped bass, with 44 AA residues and antibacterial activity against fish and human pathogens. The characterization of the precursor of piscidin- 4 of hybrid striped bass revealed a four-AA prodomain at the C-terminus [35].

We did not identify any cathelicidins in lionfish. Maybe they are not expressed in the pelvic and dorsal fins, or there is very low sequence homology between lionfish cathelicidins and those of other teleosts. In line with this hypothesis, a cathelicidin identified in Dabry's sturgeon (Acipenser dabryanus) displayed little sequence homology with other fish cathelicidins as compared to hepcidin or defensins [66]. Furthermore, cathelicidin transcripts were found in several tissues including the skin in Dabry's sturgeon [66], but especially in the spleen and kidney of Atlantic cod [27].

The different transcripts of antimicrobial peptides were expressed in the venomous spines and pelvic fin of $P$. volitans (Figure 2). The most expressed transcript was that of defensin, especially in the pelvic fin. The high expression level of this transcript could explain why only defensin was detected in the pelvic fin by mass spectrometry. The other three transcripts encoding cysteine-rich peptides were very weakly expressed and any peptide has been detected in MS/MS.

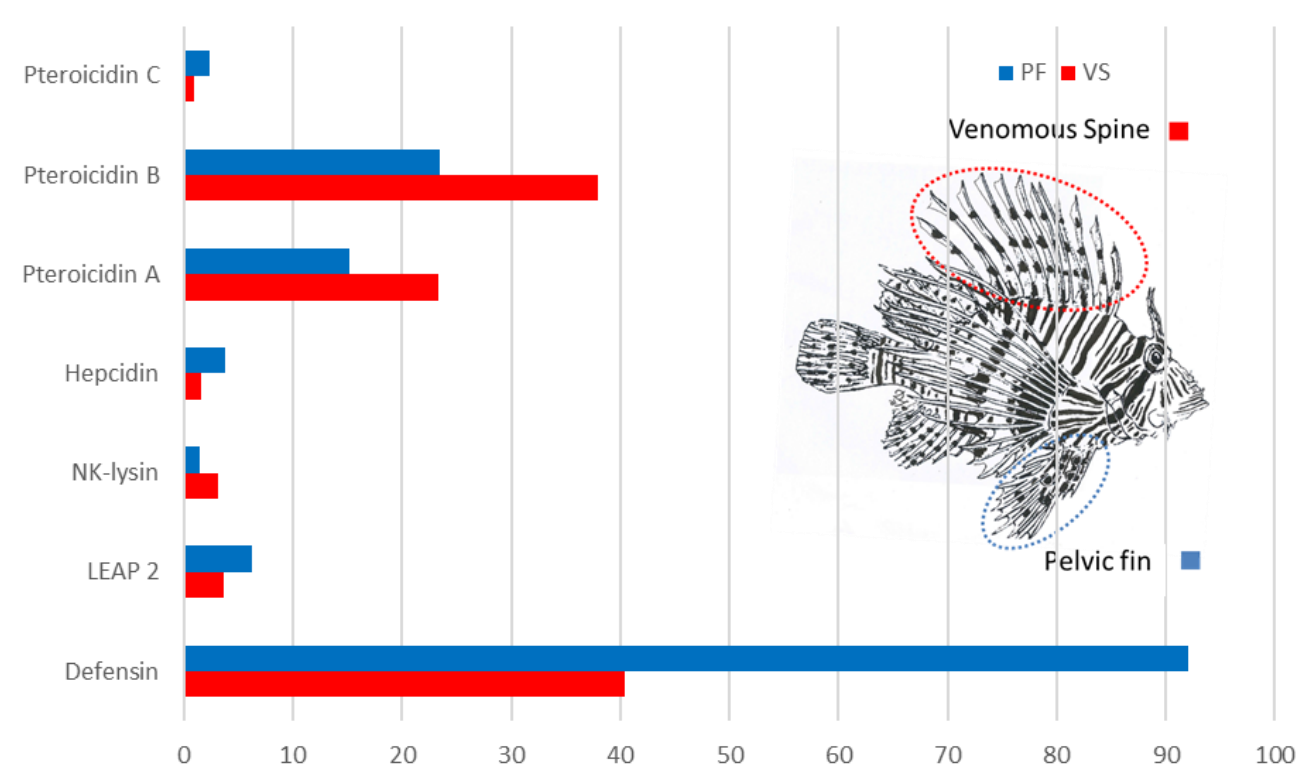

Figure 2. Expression of the different antimicrobial peptide transcripts identified in the venomous spines (red) and pelvic fin (blue) of lionfish. (FPKM = Fragments Per Kilobase of exon per Million fragments mapped).

Concerning pteroicidins, previously identified pteroicidin A [40] and pteroicidin B were more expressed, especially in the venomous spines. However, MS/MS analyses did not detect mature pteroicidins in the different pelvic fin and venomous spine samples; even $\alpha$-pteroicidins previously detected in skin [40] was not detected. This result suggests that the antimicrobial peptides derived from these precursors could be released under certain conditions like infection or by other tissues like the gills or the intestine, as described for piscidin-4 of hybrid striped bass [35] or $\alpha$-pteroicidins in skin tissue [40].

Out of all the AMPs detected by our transcriptomic approach, defensin was the only one identified in all lionfish peptidic samples, and it was only identified in the alkylated, digested sample analyzed by electrospray ionization associated to orbitrap mass spectrometry. This result shows the importance of the mass spectrometer type and of sample preparation protocol, as observed in previous studies [65,67]. Other extraction protocols could be tested on several lionfish tissues to detect mature AMPs. 


\subsection{Study of Peptides Derived from Pteroicidin B and C}

The study of antibacterial activity was carried out on peptides that could be encoded by pteroicidins B and C. Cysteine-rich peptides due to the presence of disulfide bridges have a complex three-dimensional structure and are difficult to synthesize, especially on a large scale for use in human or animal health. Therefore, we focused our study on peptides related to piscidins 4 and 7 , which are more original and have been little studied.

As we failed to detect the mature forms of the peptides derived from pteroicidins Band $\mathrm{C}$ by a peptidomics approach, eight sequences following the signal peptide corresponding to short or long forms (10 to $20 \mathrm{AA}$ ) were synthesized. We focused on piscidin-related peptides for the functional approach because piscidins are cysteine-free peptides adopting an $\alpha$-helix structure, unlike the cysteine-rich peptides identified in this study. Peptides $\beta$-Pte20, $\beta$-Pte17, $\beta$-Pte13 and $\beta$-Pte10 were derived from pteroicidin B, and $\gamma$-Pte20, $\gamma$-Pte17, $\gamma$-Pte13 and $\gamma$-Pte10 were derived from pteroicidin C. These two series of peptides were very similar in terms of their AA length but also in their physicochemical properties (Table 1). Their hydrophobicity ranged between 40 and 50\%, and their net charge varied from +3 to +6 , which is commonly observed for cationic AMPs [68].

Table 1. Physicochemical properties of the peptides selected from pteroicidins B and C.

\begin{tabular}{lccccc}
\hline Peptide & Amino Acid Sequence & $\begin{array}{c}\text { Number } \\
\text { of AA }\end{array}$ & $\begin{array}{c}\text { MW } \\
\text { (Da) }\end{array}$ & $\begin{array}{c}\text { Net } \\
\text { Charge }\end{array}$ & Hydrophobicity \\
\hline$\beta$-Pte20 & FFKRLKNAFKSARQAWRDYK & 20 & 2561 & 6 & $40 \%$ \\
$\beta$-Pte17 & FFKRLKNAFKSARQAWR & 17 & 2155 & 6 & $47 \%$ \\
$\beta$-Pte13 & FFKRLKNAFKSAR & 13 & 1613 & 5 & $46 \%$ \\
$\beta$-Pte10 & FFKRLKNAFK & 10 & 1299 & 4 & $50 \%$ \\
$\gamma$-Pte20 & FFRHLKSLWKGAKAAFRGAR & 20 & 2348 & 6 & $50 \%$ \\
$\gamma$-Pte17 & FFRHLKSLWKGAKAAFR & 17 & 2063 & 5 & $52 \%$ \\
$\gamma$-Pte13 & FFRHLKSLWKGAK & 13 & 1618 & 4 & $46 \%$ \\
$\gamma$-Pte10 & FFRHLKSLWK & 10 & 1362 & 3 & $50 \%$ \\
\hline
\end{tabular}

The peptides were tested on human, fish and oyster pathogens. All minimum inhibitory concentrations (MICs) and minimum bactericidal concentrations (MBCs) are reported in Table 2. The antibacterial spectra were peptide-specific.

The longer sequences $\beta$-Pte20, $\beta$-Pte17, $\gamma$-Pte20 and $\gamma$-Pte17 were the most active ones. They were bactericidal on human pathogens but also on the fish pathogen Aeromonas salmonicida [69] and on the oyster pathogens Vibrio aestuarianus and V. splendidus [70]. They were bactericidal on all strains except Enterococcus faecalis, whose growth was only inhibited by $\gamma$-Pte20 and $\gamma$-Pte17, with MICs of 1 to $5 \mu \mathrm{M}$. While $\gamma$-Pte20 and $\gamma$-Pte17 had a similar antibacterial effect on most of the tested strains, $\beta$-Pte17 often showed higher MICs and MBCs than $\beta$-Pte20 did.

The shorter sequences $\gamma$-Pte13 and $\gamma$-Pte10 (13 and 10 amino acids, respectively) only inhibited E. coli and A. salmonicida growth. $\beta$-Pte10 seemed to be the least active peptide: it inhibited E. coli growth only between 25 and $50 \mu \mathrm{M}$. $\beta$-Pte13 had a bacteriostatic effect on E. coli between 1 and $5 \mu \mathrm{M}$ and a bactericidal effect between 10 and $25 \mu \mathrm{M}$ (Table 2).

Regarding hemolysis (Figure 3), peptides derived from pteroicidin B and C were very weakly hemolytic at concentrations under $50 \mu \mathrm{M}$. They induced less than $5 \%$ hemolysis for $\beta$-sequences and $10 \%$ for $\gamma$-sequences. $\gamma$-Pte 20 and particularly $\gamma$-Pte17 were the most hemolytic peptides at high concentrations (19\% and $43 \%$ at $200 \mu \mathrm{M}$, respectively). The shorter peptides were very weakly hemolytic at all concentrations ( $\leq 5 \%$ hemolysis). The pteroicidin C and B peptides tested in their study had an antibacterial activity profile similar to that observed for $\alpha$-Pte-NH2 [40]. However, they were less hemolytic, with EC50 values above $200 \mu \mathrm{M}$. $\alpha$-Pte-NH2 caused 100\% hemolysis from $50 \mu \mathrm{M}$ [40]. 
Table 2. Antibacterial activity of the peptides synthesized from pteroicidin B and C precursors in $\mu \mathrm{M}$.

\begin{tabular}{|c|c|c|c|c|c|c|c|c|c|}
\hline & \multirow{3}{*}{ Bacteria } & \multicolumn{8}{|c|}{ Peptides from Pteroicidin B } \\
\hline & & \multicolumn{2}{|c|}{$\beta$-Pte20 } & \multicolumn{2}{|c|}{$\beta$-Pte17 } & \multicolumn{2}{|c|}{$\beta$-Pte13 } & \multicolumn{2}{|c|}{$\beta$-Pte10 } \\
\hline & & MIC & MBC & MIC & MBC & MIC & MBC & MIC & MBC \\
\hline \multirow{3}{*}{ Gram-positive } & Listeria monocytogenes & $1-5$ & $5-10$ & $5-10$ & $25-50$ & NA & ND & NA & ND \\
\hline & Enterococcus faecalis & NA & ND & NA & NA & NA & ND & NA & ND \\
\hline & Staphylococcus aureus & $1-5$ & $10-25$ & $10-25$ & $25-50$ & NA & ND & NA & ND \\
\hline \multirow{9}{*}{ Gram-negative } & Escherichia coli & $1-5$ & $5-10$ & $1-5$ & $1-5$ & $1-5$ & $10-25$ & $25-50$ & ND \\
\hline & Salmonella typhimurium & $10-25$ & $10-25$ & $10-25$ & $10-25$ & NA & ND & NA & ND \\
\hline & Aeromonas salmonicida & $1-5$ & $1-5$ & $5-10$ & $5-10$ & NA & ND & NA & ND \\
\hline & Vibrio aesturianus & $1-5$ & $5-10$ & $10-25$ & $10-25$ & NA & ND & NA & ND \\
\hline & Vibrio splendidus & $1-5$ & $5-10$ & $10-25$ & $10-25$ & NA & ND & NA & ND \\
\hline & Vibrio vulnificus & $5-10$ & $5-10$ & $10-25$ & $10-25$ & NA & ND & NA & ND \\
\hline & \multirow{3}{*}{ Bacteria } & \multicolumn{8}{|c|}{ Peptides from Pteroicidin C } \\
\hline & & \multicolumn{2}{|c|}{$\gamma$-Pte20 } & \multicolumn{2}{|c|}{$\gamma$-Pte17 } & \multicolumn{2}{|c|}{$\gamma$-Pte13 } & \multicolumn{2}{|c|}{$\gamma$-Pte10 } \\
\hline & & MIC & MBC & MIC & $\mathrm{MBC}$ & MIC & $\mathrm{MBC}$ & MIC & $\mathrm{MBC}$ \\
\hline \multirow{3}{*}{ Gram-positive } & Listeria monocytogenes & $1-5$ & $5-10$ & $1-5$ & $5-10$ & NA & ND & NA & ND \\
\hline & Enterococcus faecalis & $1-5$ & NA & $1-5$ & NA & NA & ND & NA & ND \\
\hline & Staphylococcus aureus & $1-5$ & $1-5$ & $1-5$ & $1-5$ & NA & ND & NA & ND \\
\hline \multirow{6}{*}{ Gram-negative } & Escherichia coli & $1-5$ & $1-5$ & $1-5$ & $10-25$ & $10-25$ & $10-25$ & $25-50$ & $25-50$ \\
\hline & Salmonella typhimurium & $5-10$ & $5-10$ & $5-10$ & $5-10$ & NA & ND & NA & ND \\
\hline & Aeromonas salmonicida & $1-5$ & $1-5$ & $1-5$ & $1-5$ & $25-50$ & NA & $25-50$ & NA \\
\hline & Vibrio aestuarianus & $5-10$ & $10-25$ & $5-10$ & $5-10$ & NA & ND & NA & ND \\
\hline & Vibrio splendidus & $5-10$ & $5-10$ & $10-25$ & $10-25$ & NA & ND & NA & ND \\
\hline & Vibrio vulnificus & $10-25$ & $10-25$ & $10-25$ & $10-25$ & NA & ND & NA & ND \\
\hline
\end{tabular}

MIC, minimum inhibitory concentration; MBC, minimum bactericidal concentration; NA, non active; ND, not determined.

The structure of an AMP as well as its physical-chemical properties are important because they can modulate its antibacterial and hemolytic activities [59]. In order to understand the different results obtained with pteroidins, we examined the helical wheel conformation of $\alpha$-Pte, $\beta$-Pte and $\gamma$-Pte. Twenty-amino-acid peptides like $\alpha$-Pte revealed a hydrophobic face and seemed to adopt an amphiphilic $\alpha$-helix. The helical wheel diagrams of $\beta$-Pte 20 and $\gamma$-Pte 20 (Figure 4) were similar and underlined a cationic face important for interactions with the bacterial membrane, e.g., interactions involving hydrophobicity [71]. Hydrophobicity, the hydrophobic moment and the angle subtended by charged residues modulate the antibacterial and hemolytic activities of peptides [72]. The high hydrophobicity level of $\alpha$-Pte compared to those of $\beta$-Pte 20 and $\gamma$-Pte 20 and its low charge can explain its hemolytic activity observed in a previous study [40]. The difference in hydrophobicity and charge observed between $\gamma$-Pte-17 $(\mathrm{H}=0.414, \mu=0.647, \Phi=5.89$, $\mathrm{z}=5)$ and $\gamma$-Pte-20 $(\mathrm{H}=0.317, \mu=0.556, \Phi=5.99, \mathrm{z}=6)$ could account for the different hemolysis rates observed at $200 \mu \mathrm{M}$.

A circular dichroism analysis was performed on the 13- to 20-AA sequences. Compared to the $\mathrm{CD}$ analysis of amidated and non-amidated $\alpha$-Pte [40] performed in the same conditions, the longest forms ( $\beta$-Pte20, $\beta$-Pte17 and $\gamma$-Pte20) seemed to have a very slight $\alpha$-helix structuring (Figure 5). Trifluoroethanol can mimic an environment conducive to $\alpha$ helix structuring, but it has certain limitations [73,74]. A medium capturing the properties of bacterial membranes might have allowed better visualization of $\alpha$-helix structuring.

Peptides $\beta$-Pte20 and $\gamma$-Pte20 possessed a broad spectrum of antibacterial activity, close to that of piscidins [5], but these peptides or shorter or longer forms were not detected by mass spectrometry. Pteroicidins $B$ and $C$ in their native forms may well be large pteroicidins like piscidins 4, 5, 6 and 7 of hybrid sea bass [34], as the alignments in Figure 1 suggest. Larger peptides are more difficult to identify by mass spectrometry; this could also partly explain why they were not detected by the peptidomic approach. As suggested by 
the alignments in Figure A2 associated to Table A1, the three lionfish pteroicidins identified in this study and in a previous study [40] appear to correspond to different classes of piscidins, as described for hybrid sea bass piscidins [34]. To confirm this, all endogenous mature forms of pteroicidins will have to be characterized.

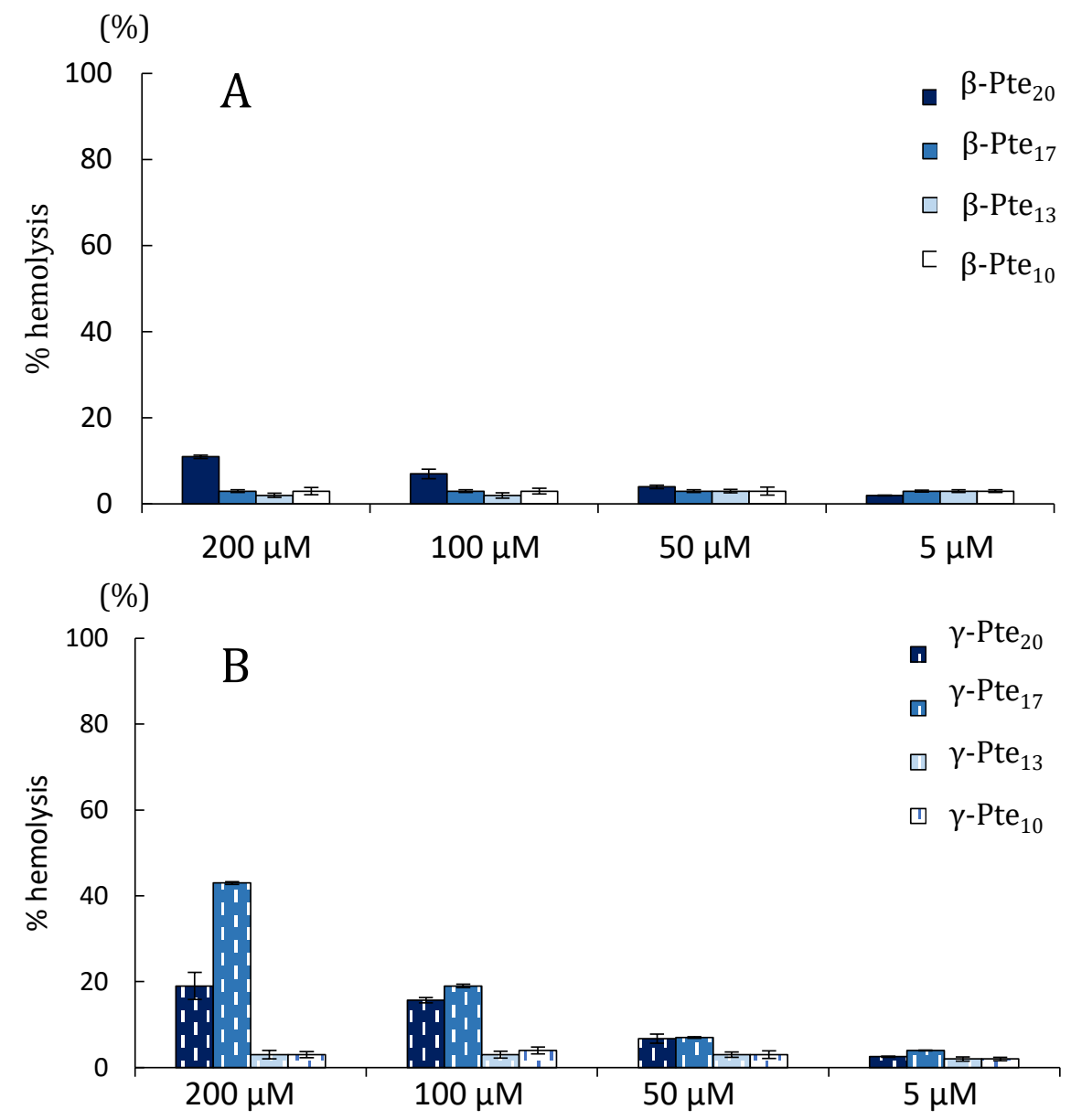

Figure 3. Hemolytic activity (\%) of the synthetic peptides. (A) $\beta$-Pte20, $\beta$-Pte17, $\beta$-Pte13 and $\beta$ Pte10; (B) $\gamma$-Pte20, $\gamma$-Pte17, $\gamma$-Pte13 and $\gamma$-Pte10 (B), Hemolytic activity was evaluated at different concentrations on human erythrocytes.
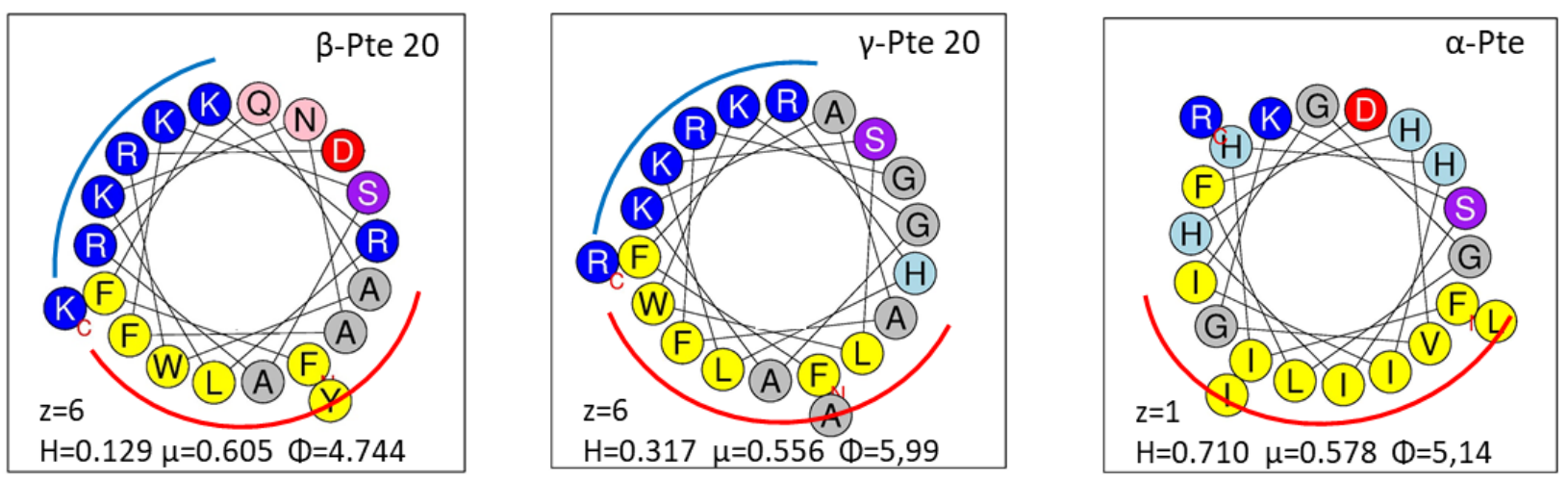

Figure 4. Helical wheel diagram of $\beta$-Pte 20, $\gamma$-Pte 20 and $\alpha$-Pte. The helical wheel projections were performed using the HeliQuest online program: https:/ / heliquest.ipmc.cnrs.fr/cgi-bin/ComputParams.py (accessed on 1 July 2008). Yellow, hydrophobic amino acids; blue, basic residues; red, acidic residues; purple and pink, polar amino acids. The red line indicates hydrophobic face, the blue line, cationic face. $z$, charge; hydrophobicity $(H)$, hydrophobic moment $(\mu)$ and angle $(\Phi)$. 


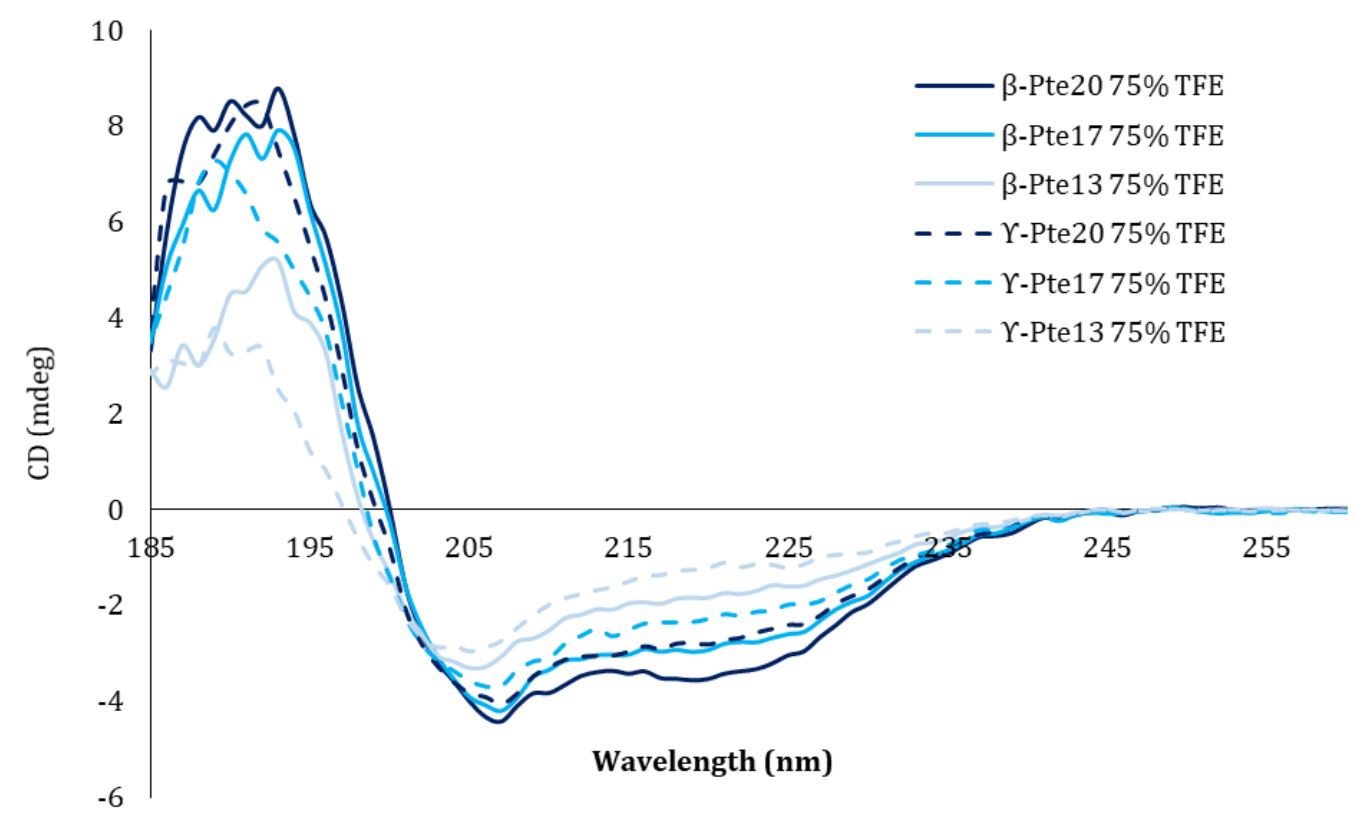

Figure 5. Circular dichroism analysis. Circular dichroism monitoring of the structuring of the peptides synthesized from pteroicidin B and pteroicidin C precursors in the presence of $75 \%$ trifluoroethanol (TFE).

This study shows that peptides from the N-terminus of certain pteroicidins can generate antibacterial peptides. This is the case for many other piscidin precursors whose native forms have not been characterized, and yet they are highly active against various pathogens in in vitro tests [75-77]. An evolutionary adaptation allowed long piscidins (even in their truncated form) to generate AMPs like histone-derived AMPs [78]. Finally, these peptides are interesting in that they do not induce hemolysis, unlike pteroicidin- $\alpha$ [40], at the concentrations at which they inhibit or are bactericidal against a range of bacteria. This is most likely due to their hydrophobicity, charge and low capacity to structure into $\alpha$-helices, unlike $\alpha$-Pte, and also raises questions as to the mode of action of these different peptides, which would be interesting to determine.

\section{Materials and Methods}

\subsection{Animal Collection}

Fish sampling was conducted by spearfishing during SCUBA diving in 2016. Lionfish total length ranged between 19 and $37 \mathrm{~cm}$, corresponding to one-and-a-half to four-anda-half-year-old animals, respectively, based on the equation proposed by Barbour and collaborators [79]. Dorsal spines and pelvic fins were dissected from twenty lionfish and stored in RNA later solution (ThermoFisher Scientific, Waltham, MA, USA) or 3\% acetic acid.

\subsection{Ethical Statement}

Pterois volitans is an invading species in the Caribbean Sea. The French Government promotes any sampling able to contribute to the eradication of the species.

\subsection{Illumina Sequencing}

Total RNA was extracted in TriReagent from the dorsal spines or pelvic fins of ten lionfish. The total RNA concentration of each sample was quantified using a NanoDrop spectrophotometer (ThermoFisher), and RNA quality was verified using a bioanalyzer (Agilent Technologies, Waldbronn, Germany). cDNA libraries were prepared with an Illumina TruSeq RNA Sample Preparation Kit v2 (Part\# 15008136 Rev. A, Illumina, San Diego, CA, USA) as described in Cornet et al. [80]. The sequencing of 150 paired-end reads was performed on a Miseq system (Illumina). 


\subsection{Bioinformatic Analysis}

Two Illumina transcriptomes were obtained from dorsal spines and pelvic fins of lionfish [39], with totals of 8,117,178 and 8,471,617 paired-end reads, respectively, with a maximal read length of $150 \mathrm{bp}$. Reads were deposited in Sequence Read Archive (SRA) under the accession numbers SRR5141017 and SRR5141018. Adapter removing from the raw reads and quality trimming were performed using Trimmomatic [81]. The transcriptome was assembled using the two libraries and the Trinity platform (https: / / github.com/trinityrnaseq/trinityrnaseq/releases/tag/Trinity-v2.1.0, accessed on 1 January 2015), a genome-independent transcriptome assembler, for de novo assembly, using the default parameters [82].

Peptide prediction was made using Transdecoder [83]. A similarity search (blastp of the Transdecoder-predicted peptides) was performed against the Uniprot-Swissprot database version 2015_06. Peptide signal prediction was studied using SignalP v4.1 [84]. Transmembrane peptides were detected using TMHMM v2.0c [85]. The protein domain search was performed using hmmscan from the hmmer v.3.1b1 suite against the Pfam-A database release 29.0 [86]. Finally, functional annotation was carried out using the Trinotate pipeline (http: / / trinotate.github.io, accessed on 1 January 2015) described by Haas and collaborators [83].

To complete the analysis and search for peptides with low sequence homology such as piscidins, we used the homemade software program PepTraq [65,87,88]. The strategy developed to search for new piscidins was to use the sequence homologies observed at the signal peptide level of the precursors encoding piscidins. These sequence homologies have been described in previous studies $[89,90]$ and correspond to the FLVL and MAEPG patterns.

Additionally, molecular weights (MW) and isoelectric points (pI) were calculated using the Expasy compute pI/Mw tool (http:/ / web.expasy.org/compute_pi/, accessed on 1 January 2015), and multiple sequence alignment was performed using CLC Main Workbench6 (CLC BIO). Domain prediction was performed with SMART (http:/ / smart. embl-heidelberg.de, accessed on 1 January 2015).

Cleaned reads were remapped for each library independently on the full transcriptome using Bowtie2 [91], and relative abundance values were estimated using RSEM (http: / / deweylab.github.io/RSEM, accessed 1 January 2018, [92]) to get FPKM (fragments per kilobase of exon per million fragments mapped) values.

PepTraq software was used for in silico analysis. Peptraq was developed to perform in silico analyses based on "-omic" data (https://peptraq.greyc.fr, accessed on 1 May 2021). The search for precursors or peptides through PepTraq can be achieved using several structural criteria, as described by Zatylny-Gaudin and collaborators [65] for neuropeptides or by Houyvet and collaborators [87] or Benoist and collaborators [92] for antibacterial peptides.

\subsection{Peptidomic Analysis}

One gram of dorsal spines or pelvic fin obtained from five lionfish was homogenized in acetic acid $3 \%$ at a $1: 10(w / v)$ ratio and centrifuged $20 \mathrm{~min}$ at $35,000 \times g$ at $4{ }^{\circ} \mathrm{C}$. The supernatants were concentrated on Sep-pak C18 cartridges (Waters, Milford, MA, USA) and dried in a speed-vacuum. Each sample was reduced with $100 \mathrm{mM}$ DTT at $55^{\circ} \mathrm{C}$ for $60 \mathrm{~min}$, and alkylated with $50 \mathrm{mM}$ iodoacetamide at $55^{\circ} \mathrm{C}$ for $45 \mathrm{~min}$. Half of the alkylated and reduced samples were hydrolyzed with trypsin at $25 \mathrm{ng} / \mu \mathrm{L}$ at $37^{\circ} \mathrm{C}$ to recover larger peptides. The resulting peptides were analyzed by NanoLC-MALDI-TOF/TOF and NanoLC-ESI-LTQ-Orbitrap as described in [65].

\subsection{Selection and Synthesis of Peptides from Pteroicidins B and C}

Eight peptides were selected from the precursors of pteroicidins B and C. For each of them, the first 20 amino acids located after the cleavage site of the signal peptide constituted the parent peptides, which were the longest peptides. These peptides were subdivided into 3 truncated forms of 17,13 and 10 amino acids according to the potential monobasic cleav- 
age sites (see Table 3). The physico-chemical properties including the charge, and molar mass of each of these peptides were determined with the software program available online from the Antimicrobial Peptide Database https: / /aps.unmc.edu/, accessed on 1 August 2003) [93] and Heliquest. The helical wheel projection diagrams of peptides were predicted using Heliquest [94] (http:/ / heliq uest.ipmc.cnrs.fr/cgibin/ComputParamsV2.py, accessed on 1 July 2008).

Table 3. List of the bacterial strains used in this study.

\begin{tabular}{ccccc}
\hline \multirow{2}{*}{ Bacterial Strain } & $\begin{array}{c}\text { Reference } \\
\text { Number }\end{array}$ & $\begin{array}{c}\text { Culture } \\
\text { Medium }\end{array}$ & Temperature \\
\hline \multirow{3}{*}{ Gram-positive } & Listeria monocytogenes & CIP 110871 & BHI & 37 \\
& Enterococcus faecalis & CIP 76.117 & LB & 37 \\
& Staphylococcus aureus & CIP 53.1 56 & CL & 37 \\
\hline \multirow{5}{*}{ Gram-negative } & Escherichia coli & CIP 54.8T & LB & 37 \\
& Salmonella typhimurium & CIP 103446 & TSB & 37 \\
& Aeromonas salmonicida & CIP 103209T & CL & 30 \\
& Vibrio aestuarianus & CIP 109791T & MB & 25 \\
& Vibrio splendidus LGP32 & CIP 107715 & MB & 25 \\
& Vibrio vulnificus & CIP 109783 & MB & 30 \\
\hline
\end{tabular}

CIP: Collection of the Institut Pasteur. MB: Marine Broth (Conda): $40.20 \mathrm{~g} / \mathrm{L}, \mathrm{pH}$ 7.6; LB, Luria-Bertani: peptone $10 \mathrm{~g} / \mathrm{L}$, yeast extract $5 \mathrm{~g} / \mathrm{L}, \mathrm{NaCI} 10 \mathrm{~g} / \mathrm{L}, \mathrm{pH}$ 7.5; BHI, Brain Heart Infusion (Difco): $37 \mathrm{~g} / \mathrm{L}, \mathrm{pH}$ 7.4; TSB, Trypticasein Soy Broth (Conda): 30 g/L, pH 7.3; CL, Columbia broth (Conda): 35 g/L, pH 7.4.

\subsection{Antimicrobial Assay}

The antibacterial activity of peptides $\beta$-Pte20, $\beta$-Pte17, $\beta$-Pte13 and $\beta$-Pte10 from pteroicidin B and $\gamma$-Pte20, $\gamma$-Pte17, $\gamma$-Pte13 and $\gamma$-Pte10 from pteroicidin C was evaluated on several bacteria as presented in Table 3. All peptides were solubilized in sterilized water. The minimum inhibitory concentrations (MICs) were determined according to the liquid growth inhibition test following the protocol established by Hetru and Bulet [95] and used for the study of $\alpha$-pteroicidins [40]. Briefly, $10 \mu \mathrm{L}$ of peptide solution were added to $100 \mu \mathrm{L}$ of bacterial suspension at a starting $\mathrm{OD}_{600}$ of $0.001\left(\sim 10^{5}\right.$ to $10^{6} \mathrm{CFU} / \mathrm{mL}$ according to strain) and incubated in 96-well microplates. The culture media of the different bacteria are listed in Table 1. Bacterial growth was assessed by optical density measurement at $595 \mathrm{~nm}$ after $16 \mathrm{~h}$ of incubation. All the tests were performed three times, and each peptide concentration between 0.1 and $50 \mu \mathrm{M}$ was tested in triplicate. MICs were expressed in $\mu \mathrm{M}$ as an [a]-[b] concentration interval where [a] was the last concentration with bacterial growth and $[\mathrm{b}]$ was the first concentration with $100 \%$ bacterial growth inhibition. MBCs (minimal bactericidal concentrations) were expressed in $\mu \mathrm{M}$ as an [a]-[b] concentration interval where [a] was the last concentration with bacterial growth and [b] was the first concentration that killed $100 \%$ of the bacteria, determined after the plating on agar plates [95].

\subsection{Hemolytic Assay}

The hemolytic activity of peptides $\beta$-Pte20, $\beta$-Pte17, $\beta$-Pte13 and $\beta$-Pte10 from pteroicidin B and $\gamma$-Pte20, $\gamma$-Pte17, $\gamma$-Pte13 and $\gamma$-Pte10 from pteroicidin $C$ was evaluated on human red blood cells (RBCs) following the protocol previously described in [96] and used for $\alpha$-Pte in a previous study [40]. RBCs were obtained from nine blood samples from French blood donors thanks to the support of the Etablissement Français du Sang (EFS). RBCs were rinsed twice in PBS and then diluted to obtain a $1 \%$ erythrocyte solution $\left(\sim 5 \times 10^{6}\right.$ cells determined using a Scepter ${ }^{\mathrm{TM}} 2.0$ cell counter). Ninety $\mu \mathrm{L}$ of erythrocyte solution were incubated with $90 \mu \mathrm{L}$ of peptide solution at concentrations ranging from 5 to $200 \mu \mathrm{M}$, for one hour at $37^{\circ} \mathrm{C}$ without shaking. The percentage of hemolysis was determined by optical density measurement at $415 \mathrm{~nm}$. The experiment was performed in triplicate. The $0 \%$ hemolysis and $100 \%$ hemolysis controls were determined in PBS and 1\% Triton X-100, respectively. 


\subsection{Structural Circular Dichroism Study}

The structural properties of peptides $\beta$-Pte20, $\beta$-Pte17, $\beta$-Pte13 and $\beta$-Pte10 from pteroicidin B and $\gamma$-Pte20, $\gamma$-Pte17, $\gamma$-Pte13 and $\gamma$-Pte10 from pteroicidin $C$ were evaluated by circular dichroism. The peptides were studied at a concentration of $0.1 \mathrm{mg} / \mathrm{mL}$ diluted in PBS buffer or in 35\% and 75\% trifluoroethanol (TFE). CD spectra were obtained using a J810 spectrometer (JASCO, Woonsocket, RI, USA) in a 1-mm long cell. The CD spectra and the helix contents were analyzed by the method developed by Micsonai and co-workers [97] and the software program BESTSEL available online https:/ / bestsel.elte.hu/ accessed on 1 January 2015.

\section{Conclusions}

The present study reports for the first time the identification of four cysteine-rich antimicrobial peptides in the Scorpaenidae family: hepcidin, LEAP-2-RP, NK-lysin-RP, and $\beta$-defensin. No cathelicidin was identified. Two new pteroicidin precursors-B and $C$-were identified using conserved motifs within the signal-peptide-coding sequence of piscidin precursors. The discovery of these two precursors in the lionfish shows that lionfish has three categories of piscidins, like other teleosts., Eight peptides of 10 to 20 amino acids were synthesized from pteroicidins B and C. Functional tests showed that whatever the original precursor, the longest forms were the most active ones on the different bacteria tested including human, fish and oyster pathogens. These non-hemolytic antibacterial peptides could constitute an alternative to antibiotics for humans but also for aquatic organisms present in aquaculture facilities, particularly in hatcheries.

Author Contributions: Conceptualization, C.Z.-G.; methodology, C.Z.-G. and B.H.; software, E.C.; validation, C.Z.-G., B.H. and E.C.; resources, Y.B.-N. and C.B.; writing-original draft preparation, C.Z.-G. and B.H.; supervision, C.Z.-G.; All authors have read and agreed to the published version of the manuscript.

Funding: This research received no external funding.

Institutional Review Board Statement: Ethical review and approval were waived for this study, due to the lionfish Pterois volitans is an invading species in the Caribbean Sea. The French Government promotes any sampling able to contribute to the eradication of the species.

Informed Consent Statement: Not applicable.

Data Availability Statement: https:/ /www.ncbi.nlm.nih.gov/bioproject/?term=prjna360033 (accessed on 1 January 2015); https:/ / www.ncbi.nlm.nih.gov / bioproject/?term=prjna360035 (accessed on 1 January 2015).

Acknowledgments: Sequencing was performed by the SéSAME platform (François Baclesse Center, Caen, France). We thank Dominique Vaur, Angelina Legros Antoine Rousselin and Nicolas Goardon for their hospitality and technical support. We also thank Pierre-Yves Buys and Laurent Fouré (Cité de la mer, Cherbourg, France). Circular dichroism analyses were performed by the optical spectroscopy platform of the Molecular Biophysics Centre (UPR 4301, CNRS, Orléans, France). We would like to thank Sandrine Villette for carrying out the CD analyses. We thank Benoit Bernay (Platform Proteogen, Caen, France) and Alexandra Kraut (iRTSV-BGE, Grenoble, France) for mass spectrometry analysis.

Conflicts of Interest: The authors declare no conflict of interest. 
Appendix A

20

10

On-piscidin-4 MKCT I LFLVLSMVVLMAEPGEGF IHH I I GGLFSAGKA IHRLIRRRRRGELQLEQELQQQLEQLEKLQQQEKLNQRFNREOLKRERVAFN 89

Lc-piscidin-3-T5.3 MKGVMIFLVLTLVVLMAGECLGGDNYGT F SGSNGNNFQHG SNSNNON SGYQL YR SRWOR SAR S P PVHCYDYS PWTT SHGNGR FP PNYD- 88

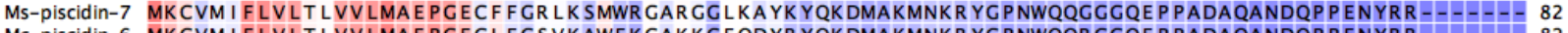
Mc-piscidin-6 MKCVM I FLVLTLVVLMAEPGECLFGSVKAWFKGAKKGFQDYR YQKDMAKMNKRYGPNWQQR GGQEPPADAQANDQP PENYRR------- 82 Ms-piscidin-6 MKCVM I FLVLT LVVLMAEPGECLFGSVKAWFKGGKKGFQDYR YQKDMAKMNKR YGPNWQQRGCQEP PADAQANDQP PENYRR------- 82 Mc-moronecidin MKCATLSLVLSMVVLMAEPGDAFFHHI FR I VHVGKT I HKLVTGGKAEQDQQDQQYQQDQQDQQAQQYQR FNRERAAFD-------- 79 DI-dicentracin MKCAT LFLVL SMVVLMAEPGDAFFHH I FRG IVHVGKS I HK LVTGGKAQQDQQDQQYQQDQQDQQAEQYQRFNRERAAFD-- - - - - 79

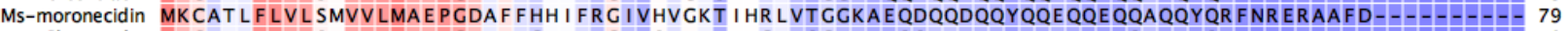
Ch-piscidin MKCATRFLVLSMVVLMAEPGDAFFGHLYRG ITSVVKHVHGLLSGETPRQQEVMKEAMREAMKVQEAMDQEAFDRERALV- - - - - - - 79 Pc-moronecidin MKCTTVFLVLSMVVLMAEPGDAFFGHLFRG I INVGKH I HGLLSGETPRQQEVMKEAMREAMKVQEAMDQQAFDRQRALA- - - - - - 79 On-piscidin-2 MKCAAVFLMLSMV I LMAEPGECIWDA I FHGAKHFLHRLVNGPPFLRQFLQVVFVLVVFLVELDKRA ISYHPRRLNFD--

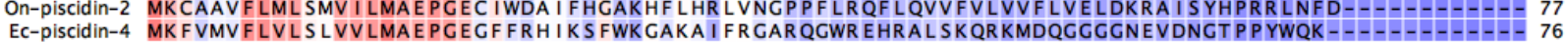

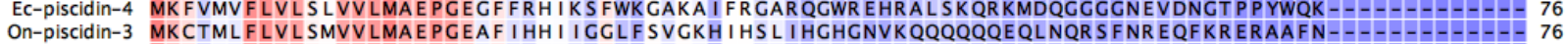

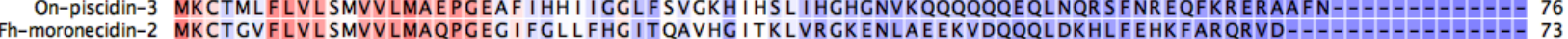

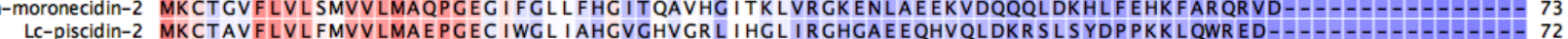
Lc-piscidin-2 MKCTAVFLVLFMVVLMAEPGEC I WGL I AHGVGHVGRL I HGL IRGHGAEEQHVQLDKR SLSYDPPKKLQWRED--
Mc-piscidin-5 MKCVM I FLVLTLVVLMAEPGEGL I GSLFRGAKA I FRGARQGWR SHKAVSRYRARYVRR PV IYYHRVYPNEER--

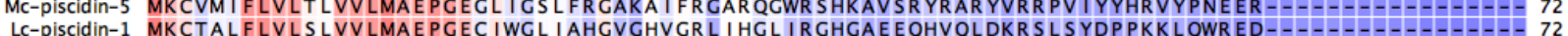
LC-piscidin-1 MKCTALFLLSLVLAEPCC

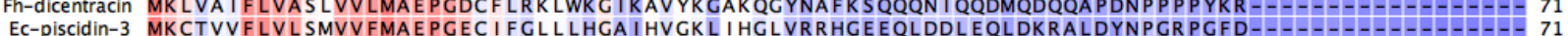

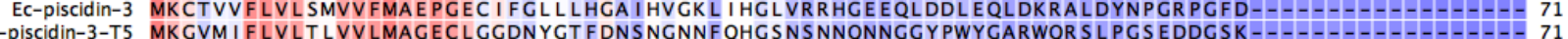
Lc-piscidin-3-T5 MKGVM I FLVLT LVVLMAGECLGGDNYGT FDNSNGNNFQHGSNSNNQNNGCYPWYGARWQR SLPGS EDDGSK-1- - -

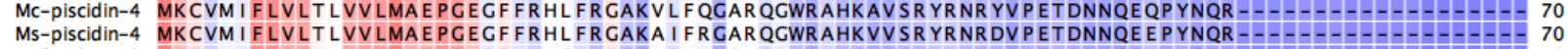

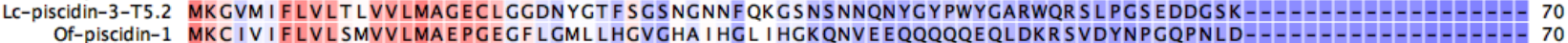

Ea-piscid in MRCIALFLVLSLVVLMAEPGEGFFFHI I EGL I HAGRM I HRFVHRRRHRHGMEELQDLDQRAFERESAFA -

Af-Moronecid in MKC I T L FLVLS LVVLMAEPGECFFHHH I YHGY I KLHQA I RCLVRAAHHGAMTEQQEMEQRAFDRERAFA- - - - - - - - - - - -

Eb-piscidin MRCIALFFVLSLVVLMAEPGEGFFFH I I KGLFHAGKM I HGL I HRRRHRHGMEELQDLDQRAFEREKAFA

Ec-piscidin-1 MRCI AL FLVLSLVVLTAEPGEGFLFH I I KGL I HAGRM I HR FVHRRRHRHGMEELQDLDQRAFDRERAFA - - - - - - - - - - -

Ef-piscidin MRCIALFLVLSLVALMAEPGEGF I FHI I KGLVHAGKM I HGLVTRRRHRHGMEELQDLDQRAFEREKAFA-

Ec-piscidin-2 MRC IALFLVLSLVVLMAEPGEGFFFH I VKGL FHAGRM I HGLVNRRRHR HGMEELDLDQRAFEREKAFA -

Em-piscidin-2 MRC I ALFLVLSLVVLMAEPGEGFFFH I I KGL FHAGRM I HGLVNRRRHRHGMEELDLDQRAFEREKAFA-

p-pleurocidin-AP3 MKFTANFLMLF I FVLMFEPGECGWRTLLKKAEVKTVGKLALKHYLGKQPELDKRA IDDDPS IIVFD-

So-piscidin MKCTAVFLVLFMVVLMAEPGEC IWGL I AHGVAHVGS L I HGLVNGNHGGNQAEEQQEQLNKR SLSYDHP-

On-piscidin-1 MKSAV I FLAL FMVFMMAEPGECFDWDSVLKGVEGFVRGYFGKEKAKELVKSLKADFQNYKHLRQREFD-_...-

Pa-pleurocid in MKFTATFLMMA I FVLMVEPGECGWG SFFKKAAHVGKHVGKAALTHYLGDKQELNKRAVDEDPNV IVFE- - - - - - - - - - - 68

Pa-pleurocidin-4 MKFTAT FLMMF I FVLMVEPGECGWGS I FKHGR HAAKH I GHAAVNHYLGEQQDLDKRAVDEDPNV IVFE- - - - - - - - - - -

Hp-pleurocidin-AP2 MKFTATFLMLF I FVLMVEPGECGWK KWFNRAKKVGKTVGGLAVDHYLGKQPELDKRAVDEDPSA IVFD-- - - - - - - - - - - 68

Hp-pleurocidin-AP1 MKFTATFLMLF I FVLMVEPGECGWK SVFRKAKKVGKTVGGLALDHYLGEQQELDKRAVDEDPSA IVFD-

Pa-pleurocidin-5 MKLAAAFLVLFLVVLMAEPGESFLGFLFHGIRHG IKA I HGMIHGNSLDEMQELDKRSFDDNPNA IVFD-

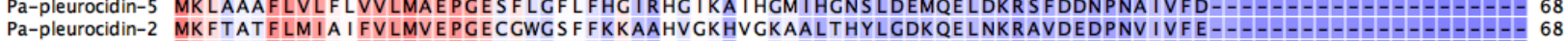

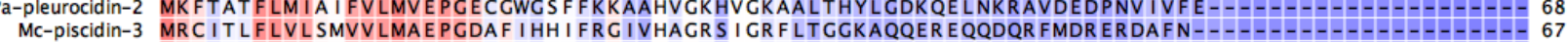

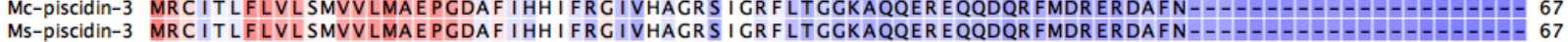

Sc-moronecid in MKCTALFLVLSLVVLMAEPGDA I FHHIFKG IVHVGKT I HRLVTCGQNMKDQQKLEQR SFDQERAAFD-

Gc-pleurocidin-3.8 MKFTATFLVLFMVVLMAGSGECGWK KWLR KGAKHLGQAA IKGLASCEEOQELDKR SMDDEPSAIVFDAf-dicentracin MKC I L L FLVLSLVVLMAEPGECF I HHIFNGLVKVGKS I HGL IRRRHGAMTEQQEMEQRAFDREQAFA Pa-pleurocidin-6 MKFATAFLML SMVVLMAEPGECR STEDI I KS I SGGCFL NAMNAGYNEQQELNKR SDDDDS PSL IVFD

Em-piscidin-1 MRCIALFLVLSLVVLMAEPGEGF IFH I I KGLFHAGKM I HGLVTRRRHGVEELQDLDQRAFEREKAFA- - - - - - - - - - - - - 67

Of-moronecidin MKC I T LFLVLSMVVLMAEPGEAFFHH I FNGLVGVGKT I HRL I TGGRNQQDQKELDKR FLNQQQAAFN- - - - - - -

Pteroicidin-A MKC I ALFLVLSMVVLMAEPGEAF I HH I I GGL FHVGK S I HDL I RGKNRDMAEQQELERAFDRERAFA-

SI-piscid in MKF I GLFLVLSLVVLMAEPGEGFFHH I LSG I FHVGKM I HGA IQRRR HGMTELEQEQFDRDRADFA Gc-pleurocidin-Sc4B7 MKFTAT F LVLFMVVLMAEPGEG FWGK L LK LGMHG I GL LHQHLGADEQQE LDER SEEDEPNV IVFE-

On-piscidin-5 MKSA I I FLVFT LVLFMADPAELQLQGKQV SGEVVQKVLQEL I QSVAKPGPKDVNFNEFEDAVMS - - - - - - - - - - -

Gc-pleurocidin-3.2 MKFTATFLVLFMVVLMAGSGECGWKKWFT KGERLSQRHFADVEQQELDKR SVDDEPSS IAFD

Pa-pleurocidin-3 MKFTATFLVLSLVVLMAEPGECFLGAL I KGA I HGGR F I HGM I QNHHGYDEQQELNKRAVDE-

Gm-gaduscidin-1 MRY I VLLVVVLLLAMMVQPADCF I HH I I GW I S HGVRA I HRA I HGEKAEEY IMVD

Gm-piscidin-2- MRC I FLLFVVLLLAMMVLPAEGF LHH I VGL I HHGKLDMYR SNNCSLV_-

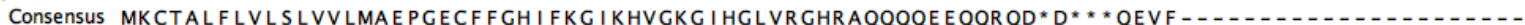

Figure A1. Alignment of piscidins showing sequence homologies in the signal peptide. 


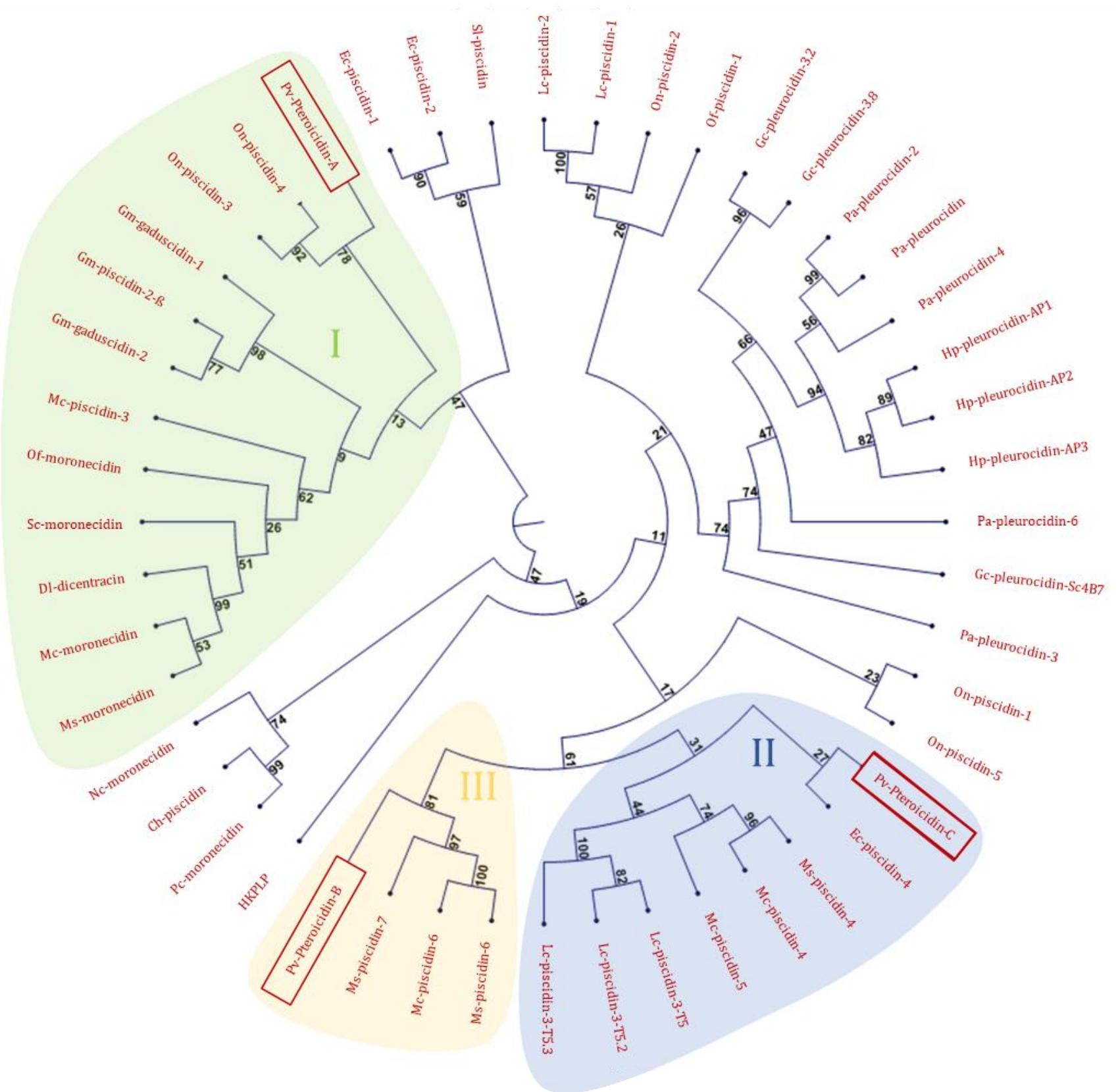

Figure A2. Study of the phylogenetic relationships of Pterois volitans pteroicidins with other piscidins. The phylogenetic analysis was performed using the neighbor-joining method. The results are presented as a circular cladogram. The confidence interval was evaluated with the bootstrap method with 1000 simulations. The values are percentages. The analysis was performed with the sequences detailed in Table A1. Pteroicidins A, B and C are framed in red. The classification proposed by Salger et al. (2016) extended to the closest piscidins is indicated by the following colors: green (class I), blue (class II) and yellow (class III).

Table A1. Accession numbers of the piscidins used for the phylogeny study.

\begin{tabular}{llc}
\hline Sequence Name & Origin & Accession Number \\
\hline Ch-piscidin & Chionodraco hamatus (Lönberg, 1905) (crocodile icefish) & CBX55949.1 \\
Dl-dicentracin & Dicentrarchus labrax (Linnaeus, 1758) (sea bass) & P59906.1 \\
Ec-piscidin-2 & & ADY86111.1 \\
Ec-piscidin-1 & Epinephelus coioides (Hamilton, 1822) (orange-spotted grouper) & ACE78291.1 \\
Ec-piscidin-4 & & AKA60777.2 \\
\hline
\end{tabular}


Table A1. Cont.

\begin{tabular}{|c|c|c|}
\hline Sequence Name & Origin & Accession Number \\
\hline Gm-gaduscidin-1 & \multirow{4}{*}{ Gadus morhua 1758 (Atlantic cod) } & ACS91329.1 \\
\hline Gm-piscidin-2- $\Omega$ & & ADU34223.1 \\
\hline Gm-gaduscidin-2 & & ADK63424.1 \\
\hline Gc-pleurocidin-3.8 & & AAP55799.1 \\
\hline Gc-pleurocidin-3.2 & \multirow[t]{2}{*}{ Glyptocephalus cynoglossus (Linnaeus, 1758) (witch flounder) } & AAP55800.1 \\
\hline Gc-pleurocidin-Sc4B7 & & AAP55798.1 \\
\hline Hp-pleurocidin-AP3 & \multirow{4}{*}{ Hippoglossoides platessoides (Fabrissius, 1780) (american plaice) } & ABB70232.1 \\
\hline Hp-pleurocidin-AP2 & & AAP55794.1 \\
\hline Hp-pleurocidin-AP1 & & AAP55793.1 \\
\hline Lc-piscidin-1 & & ACE78289.1 \\
\hline Lc-piscidin-2 & \multirow{4}{*}{ Larimichthys crocea (Richardson, 1846) (large yellowcroaker) } & AGN52988.1 \\
\hline Lc-piscidin-3-T5.2 & & AIL82389.1 \\
\hline Lc-piscidin-3-T5 & & AIL82388.1 \\
\hline Lc-piscidin-3-T5.3 & & AQS27931.1 \\
\hline Mc-piscidin-6 & \multirow{6}{*}{ Morone chrysops (Rafinesque, 1820) (white bass) } & APQ32044.1 \\
\hline Mc-piscidin-5 & & ADP37960.1 \\
\hline Mc-piscidin-3 & & APQ32046.1 \\
\hline Mc-piscidin-4 & & APQ32050.1 \\
\hline Mc-moronecidin & & Q8UUUG2.1 \\
\hline Ms-moronecidin & & Q̄8UUG0.1 \\
\hline Ms-piscidin-4 & \multirow{3}{*}{ Morone saxatilis (Walbaun, 1792) (striped bass) } & ADP37959.1 \\
\hline Ms-piscidin-6 & & APQ32043.1 \\
\hline Ms-piscidin-7 & & APQ32054.1 \\
\hline Of-piscidin-1 & \multirow{3}{*}{ Oplegnathus fasciatus (Temminck \& Schlegel, 1844) (barred knifejaw) } & BAM99884.1 \\
\hline Of-moronecidin & & KT354978 \\
\hline On-piscidin-4 & & AGA16547.1 \\
\hline On-piscidin-3 & \multirow{4}{*}{ Oreochromis niloticus (Linnaeus, 1758) (Nile tilapia) } & AGA16546.1 \\
\hline On-piscidin-5 & & AGA16548.1 \\
\hline On-piscidin-2 & & AGA16545.1 \\
\hline On-piscidin-1 & & AGA16544.1 \\
\hline Pc-moronecidin & \multirow[t]{3}{*}{ Parachaenichthys charcoti (Vaillant, 1906) (Antartic dragon fish) } & AOW44479.1 \\
\hline Pa-pleurocidin & & P81941.2 \\
\hline Pa-pleurocidin-2 & & Q90ZY0.1 \\
\hline Pa-pleurocidin- 4 & \multirow[t]{3}{*}{ Pseudopleuronectes americanus (Walbaun, 1792) (winter flounder) } & Q90ZX8.1 \\
\hline Pa-pleurocidin-3 & & Q90VW7.1 \\
\hline Pa-pleurocidin- 6 & & AAQ16623.1 \\
\hline Sl-piscidin & Seriola lalandi (Valenciennes, 183)3 (yellowtail amberjack) & ARK85994.1 \\
\hline Sc-moronecidin & Siniperca chuatsi (Basilewsky, 1855) (mandarin fish) & AAV65044.1 \\
\hline Pv-Pteroicidin-A & \multirow{3}{*}{ Pterois volitans (Linnaeus, 1758) (red lion-fish) } & This study \\
\hline Pv-Pteroicidin-B & & This study \\
\hline Pv-Pteroicidin-C & & This study \\
\hline Nc-moronecidin & Notothenia coriiceps (Richardson, 1844) (black rockcod) & XP_010768425.1. \\
\hline HKPLP & Hippocampus kuda (Bleeker, 1852) (spotted seahorse) & AAX58115.1 \\
\hline
\end{tabular}

\section{References}

1. Ganz, T.; Lehrer, R.I. Antimicrobial peptides of vertebrates. Curr. Opin. Immunol. 1998, 10, 41-44. [CrossRef]

2. Hoffmann, J.A.; Kafatos, F.C.; Janeway, C.; Ezekowitz, R. Phylogenetic perspectives in innate immunity. Science 1999, 284, 1313-1318. [CrossRef]

3. Lehrer, R.I.; Ganz, T. Antimicrobial peptides in mammalian and insect host defence. Curr. Opin. Immunol. 1999, $11,23-27$. [CrossRef]

4. Zasloff, M. Antimicrobial peptides of multicellular organisms. Nature 2002, 415, 389-395. [CrossRef] [PubMed]

5. Masso-Silva, J.; Diamond, G. Antimicrobial peptides from fish. Pharmaceuticals 2014, 7, 265-310. [CrossRef]

6. Shike, H.; Lauth, X.; Westerman, M.E.; Ostland, V.E.; Carlberg, J.M.; Van Olst, J.C.; Shimizu, C.; Bulet, P.; Burns, J.C. Bass hepcidin is a novel antimicrobial peptide induced by bacterial challenge. Eur. J. Biochem. 2002, 269, 2232-2237. [CrossRef]

7. Douglas, S.E.; Gallant, J.W.; Liebscher, R.S.; Dacanay, A.; Tsoi, S.C. Identification and expression analysis of hepcidin-like antimicrobial peptides in bony fish. Dev. Comp. Immunol. 2003, 27, 589-601. [CrossRef] 
8. Yang, M.; Chen, B.; Cai, J.-J.; Peng, H.; Cai, L.; Yuan, J.-J.; Wang, K.-J. Molecular characterization of hepcidin AS-hepc2 and AShepc6 in black porgy (Acanthopagrus schlegelii): Expression pattern responded to bacterial challenge and in vitro antimicrobial activity. Comp. Biochem. Physiol. Part B Biochem. Mol. Biol. 2011, 158, 155-163. [CrossRef]

9. Lauth, X.; Babon, J.J.; Stannard, J.A.; Singh, S.; Nizet, V.; Carlberg, J.M.; Ostland, V.E.; Pennington, M.W.; Norton, R.S.; Westerman, M.E. Bass hepcidin synthesis, solution structure, antimicrobial activities and synergism, and in vivo hepatic response to bacterial infections. J. Biol. Chem. 2005, 280, 9272-9282. [CrossRef] [PubMed]

10. Rodrigues, P.N.S.; Vázquez-Dorado, S.; Neves, J.V.; Wilson, J.M. Dual function of fish hepcidin: Response to experimental iron overload and bacterial infection in sea bass (Dicentrarchus labrax). Dev. Comp. Immunol. 2006, 30, 1156-1167. [CrossRef]

11. Zhang, Y.-A.; Zou, J.; Chang, C.-I.; Secombes, C.J. Discovery and characterization of two types of liver-expressed antimicrobial peptide 2 (LEAP-2) genes in rainbow trout. Vet. Immunol. Immunopathol. 2004, 101, 259-269. [CrossRef]

12. Yang, G.; Guo, H.; Li, H.; Shan, S.; Zhang, X.; Rombout, J.H.W.M.; An, L. Molecular characterization of LEAP-2 cDNA in common carp (Cyprinus carpio L.) and the differential expression upon a Vibrio anguillarum stimulus; indications for a significant immune role in skin. Fish Shellfish Immunol. 2014, 37, 22-29. [CrossRef] [PubMed]

13. Liu, T.; Gao, Y.; Wang, R.; Xu, T. Characterization, evolution and functional analysis of the liver-expressed antimicrobial peptide 2 (LEAP-2) gene in miiuy croaker. Fish Shellfish Immunol. 2014, 41, 191-199. [CrossRef]

14. Borkar, S.; Nandanwar, S.; Lee, J.; Kim, H. Characterization of Four Liver-Expressed Antimicrobial Peptides from Antarctic Fish and Their Antibacterial Activity. Appl. Sci. 2019, 9, 4299. [CrossRef]

15. Shafee, T.M.A.; Lay, F.T.; Phan, T.K.; Anderson, M.A.; Hulett, M.D. Convergent evolution of defensin sequence, structure and function. Cell. Mol. Life Sci. 2016, 1-20. [CrossRef]

16. Ganz, T. Defensins: Antimicrobial peptides of innate immunity. Nat. Rev. Immunol. 2003, 3, 710-720. [CrossRef]

17. Cuesta, A.; Meseguer, J.; Esteban, M.Á. Molecular and functional characterization of the gilthead seabream $\beta$-defensin demonstrate its chemotactic and antimicrobial activity. Mol. Immunol. 2011, 48, 1432-1438. [CrossRef]

18. Zou, J.; Mercier, C.; Koussounadis, A.; Secombes, C. Discovery of multiple beta-defensin like homologues in teleost fish. Mol. Immunol. 2007, 44, 638-647. [CrossRef] [PubMed]

19. Casadei, E.; Wang, T.; Zou, J.; González Vecino, J.L.; Wadsworth, S.; Secombes, C.J. Characterization of three novel $\beta$-defensin antimicrobial peptides in rainbow trout (Oncorhynchus mykiss). Mol. Immunol. 2009, 46, 3358-3366. [CrossRef]

20. Zhao, J.G.; Zhou, L.; Jin, J.Y.; Zhao, Z.; Lan, J.; Zhang, Y.B.; Zhang, Q.Y.; Gui, J.F. Antimicrobial activity-specific to Gram-negative bacteria and immune modulation-mediated NF-kB and Sp1 of a medaka $\beta$-defensin. Dev. Comp. Immunol. 2009, 33, 624-637. [CrossRef]

21. Jin, J.-Y.; Zhou, L.; Wang, Y.; Li, Z.; Zhao, J.-G.; Zhang, Q.-Y.; Gui, J.-F. Antibacterial and antiviral roles of a fish $\beta$-defensin expressed both in pituitary and testis. PLoS One 2010, 5, e12883. [CrossRef]

22. Hirono, I.; Kondo, H.; Koyama, T.; Arma, N.R.; Hwang, J.Y.; Nozaki, R.; Midorikawa, N.; Aoki, T. Characterization of Japanese flounder (Paralichthys olivaceus) NK-lysin, an antimicrobial peptide. Fish Shellfish Immunol. 2007, 22, 567-575. [CrossRef]

23. Zhou, Q.-J.; Wang, J.; Liu, M.; Qiao, Y.; Hong, W.-S.; Su, Y.-Q.; Han, K.-H.; Ke, Q.-Z.; Zheng, W.-Q. Identification, expression and antibacterial activities of an antimicrobial peptide NK-lysin from a marine fish Larimichthys crocea. Fish Shellfish Immunol. 2016, 55, 195-202. [CrossRef]

24. Andersson, M.; Gunne, H.; Agerberth, B.; Boman, A.; Bergman, T.; Sillard, R.; Jörnvall, H.; Mutt, V.; Olsson, B.; Wigzell, H. NK-lysin, a novel effector peptide of cytotoxic T and NK cells. Structure and cDNA cloning of the porcine form, induction by interleukin 2, antibacterial and antitumour activity. EMBO J. 1995, 14, 1615-1625. [CrossRef] [PubMed]

25. Cai, S.; Wang, J.; Wang, K.; Chen, D.; Dong, X.; Liu, T.; Zeng, Y.; Wang, X.; Wu, D. Expression, Purification and Antibacterial Activity of NK-Lysin Mature Peptides from the Channel Catfish (Ictalurus punctatus). Appl. Sci. 2016, 6, 240. [CrossRef]

26. Scocchi, M.; Pallavicini, A.; Salgaro, R.; Bociek, K.; Gennaro, R. The salmonid cathelicidins: A gene family with highly varied C-terminal antimicrobial domains. Comp. Biochem. Physiol. B. Biochem. Mol. Biol. 2009, 152, 376-381. [CrossRef] [PubMed]

27. Maier, V.H.; Dorn, K.V.; Gudmundsdottir, B.K.; Gudmundsson, G.H. Characterisation of cathelicidin gene family members in divergent fish species. Mol. Immunol. 2008, 45, 3723-3730. [CrossRef] [PubMed]

28. Scocchi, M.; Furlan, M.; Venier, P.; Pallavicini, A. Cathelicidins. In Lessons in Immunity; Elsevier: Amsterdam, The Netherlands, 2016; pp. 225-237.

29. Uzzell, T.; Stolzenberg, E.D.; Shinnar, A.E.; Zasloff, M. Hagfish intestinal antimicrobial peptides are ancient cathelicidins. Peptides 2003, 24, 1655-1667. [CrossRef]

30. Chang, C.-I.; Pleguezuelos, O.; Zhang, Y.-A.; Zou, J.; Secombes, C.J. Identification of a novel cathelicidin gene in the rainbow trout, Oncorhynchus mykiss. Infect. Immun. 2005, 73, 5053-5064. [CrossRef]

31. Broekman, D.C.; Frei, D.M.; Gylfason, G.; Steinarsson, A.; Jörnvall, H.; Agerberth, B.; Gudmundsson, G.H.; Maier, V.H. Cod cathelicidin: Isolation of the mature peptide, cleavage site characterisation and developmental expression. Dev. Comp. Immunol. 2011, 35, 296-303. [CrossRef]

32. Chang, C.; Zhang, Y.; Zou, J.; Nie, P.; Secombes, C.J. Two Cathelicidin Genes Are Present in both Rainbow Trout (Oncorhynchus mykiss) and Atlantic Salmon (Salmo salar). Society 2006, 50, 185-195. [CrossRef]

33. Lu, X.J.; Chen, J.; Huang, Z.A.; Shi, Y.H.; Lv“" J.N. Identification and characterization of a novel cathelicidin from ayu, Plecoglossus altivelis. Fish Shellfish Immunol. 2011, 31, 52-57. [CrossRef] 
34. Salger, S.A.; Cassady, K.R.; Reading, B.J.; Noga, E.J. A Diverse Family of Host-Defense Peptides (Piscidins) Exhibit Specialized Anti-Bacterial and Anti-Protozoal Activities in Fishes. PLoS One 2016, 11, e0159423. [CrossRef]

35. Salger, S.A.; Reading, B.J.; Baltzegar, D.A.; Sullivan, C.V.; Noga, E.J. Molecular characterization of two isoforms of piscidin 4 from the hybrid striped bass (Morone chrysops ?? Morone saxatilis). Fish Shellfish Immunol. 2011, 30, 420-424. [CrossRef]

36. Noga, E.J.; Silphaduang, U.; Park, N.G.; Seo, J.K.; Stephenson, J.; Kozlowicz, S. Piscidin 4, a novel member of the piscidin family of antimicrobial peptides. Comp. Biochem. Physiol. - B Biochem. Mol. Biol. 2009, 152, 299-305. [CrossRef]

37. Cole, A.M. Isolation and Characterization of Pleurocidin, an Antimicrobial Peptide in the Skin Secretions of Winter Flounder. J. Biol. Chem. 1997, 272, 12008-12013. [CrossRef]

38. Silphaduang, U.; Colorni, A.; Noga, E.J. Evidence for widespread distribution of piscidin antimicrobial peptides in teleost fish. Dis. Aquat. Organ. 2006, 72, 241-252. [CrossRef] [PubMed]

39. Lauth, X.; Shike, H.; Burns, J.C.; Westerman, M.E.; Ostland, V.E.; Carlberg, J.M.; Van Olst, J.C.; Nizet, V.; Taylor, S.W.; Shimizu, C.; et al. Discovery and characterization of two isoforms of moronecidin, a novel antimicrobial peptide from hybrid striped bass. J. Biol. Chem. 2002, 277, 5030-5039. [CrossRef]

40. Houyvet, B.; Bouchon-Navaro, Y.; Bouchon, C.; Goux, D.; Bernay, B.; Corre, E.; Zatylny-Gaudin, C. Identification of a moronecidinlike antimicrobial peptide in the venomous fish Pterois volitans: Functional and structural study of pteroicidin- $\alpha$. Fish Shellfish Immunol. 2018, 72, 318-324. [CrossRef] [PubMed]

41. Schofield, P.J. Geographic extent and chronology of the invasion of non-native lionfish (Pterois volitans [Linnaeus 1758] and P. miles [Bennett 1828]) in the Western North Atlantic and Caribbean Sea. Aquat. Invasions 2009, 4, 473-479. [CrossRef]

42. Green, S.J.; Akins, J.L.; Maljković, A.; Côté, I.M. Invasive Lionfish Drive Atlantic Coral Reef Fish Declines. PLoS One 2012, 7, e32596. [CrossRef]

43. Arias-González, J.E.; González-Gándara, C.; Luis Cabrera, J.; Christensen, V. Predicted impact of the invasive lionfish Pterois volitans on the food web of a Caribbean coral reef. Environ. Res. 2011, 111, 917-925. [CrossRef] [PubMed]

44. Bullard, S.A.; Barse, A.M.; Curran, S.S.; Morris, J.A. First Record of a Digenean from Invasive Lionfish, Pterois cf. volitans, (Scorpaeniformes: Scorpaenidae) in the Northwestern Atlantic Ocean. J. Parasitol. 2011, 97, 833-837. [CrossRef] [PubMed]

45. Robert, D.; Ellis, M.E.F. Native grouper indirectly ameliorates the negative effects of invasive lionfish. Mar. Ecol. Prog. Ser. 2016, 558, 267-279. [CrossRef]

46. Maljković, A.; Van Leeuwen, T.E.; Cove, S.N. Predation on the invasive red lionfish, Pterois volitans (Pisces: Scorpaenidae), by native groupers in the Bahamas. Coral Reefs 2008, 27, 501. [CrossRef]

47. Mumby, P.J.; Harborne, A.R.; Brumbaugh, D.R. Grouper as a Natural Biocontrol of Invasive Lionfish. PLoS One 2011, 6, e21510. [CrossRef]

48. Sikkel, P.C.; Tuttle, L.J.; Cure, K.; Coile, A.M.; Hixon, M.A. Low Susceptibility of Invasive Red Lionfish (Pterois volitans) to a Generalist Ectoparasite in Both Its Introduced and Native Ranges. PLoS One 2014, 9, e95854. [CrossRef]

49. Sellers, A.J.; Ruiz, G.M.; Leung, B.; Torchin, M.E. Regional Variation in Parasite Species Richness and Abundance in the Introduced Range of the Invasive Lionfish, Pterois volitans. PLoS One 2015, 10, e0131075. [CrossRef]

50. Ramos-Ascherl, Z.; Williams, E.H.; Bunkley-Williams, L.; Tuttle, L.J.; Sikkel, P.C.; Hixon, M.A. Parasitism in Pterois volitans (Scorpaenidae) from Coastal Waters of Puerto Rico, the Cayman Islands, and the Bahamas. J. Parasitol. 2015, 101, 50-56. [CrossRef] [PubMed]

51. Harris, H.E.; Fogg, A.Q.; Allen, M.S.; Ahrens, R.N.M.; Patterson, W.F. Precipitous Declines in Northern Gulf of Mexico Invasive Lionfish Populations Following the Emergence of an Ulcerative Skin Disease. Sci. Rep. 2020, 10, 1934. [CrossRef]

52. Benkwitt, C.E.; Albins, M.A.; Buch, K.L.; Ingeman, K.E.; Kindinger, T.L.; Pusack, T.J.; Stallings, C.D.; Hixon, M.A. Is the lionfish invasion waning? Evidence from The Bahamas. Coral Reefs 2017, 36, 1255-1261. [CrossRef]

53. Kiriake, A.; Shiomi, K. Some properties and cDNA cloning of proteinaceous toxins from two species of lionfish (Pterois antennata and Pterois volitans). Toxicon 2011, 58, 494-501. [CrossRef]

54. Kiriake, A.; Madokoro, M.; Shiomi, K. Enzymatic properties and primary structures of hyaluronidases from two species of lionfish (Pterois antennata and Pterois volitans). Fish Physiol. Biochem. 2014. [CrossRef] [PubMed]

55. Hosaka, M.; Nagahama, M.; Kim, W.S.; Watanabe, T.; Hatsuzawa, K.; Ikemizu, J.; Murakami, K.; Nakayama, K. Arg-X-Lys / ArgArg motif as a signal for precursor cleavage catalyzed by furin within the constitutive secretory pathway. J. Biol. Chem. 1991, 266, 12127-12130. [CrossRef]

56. Lin, W.; Liu, S.; Hu, L.; Zhang, S. Characterization and bioactivity of hepcidin-2 in zebrafish: Dependence of antibacterial activity upon disulfide bridges. Peptides 2014, 57. [CrossRef]

57. Nemeth, E.; Preza, G.C.; Jung, C.-L.; Kaplan, J.; Waring, A.J.; Ganz, T. The N-terminus of hepcidin is essential for its interaction with ferroportin: Structure-function study. Blood 2006, 107, 328-333. [CrossRef]

58. Robertson, L.S.; Iwanowicz, L.R.; Marranca, J.M. Identification of centrarchid hepcidins and evidence that 17??-estradiol disrupts constitutive expression of hepcidin-1 and inducible expression of hepcidin-2 in largemouth bass (Micropterus salmoides). Fish Shellfish Immunol. 2009, 26, 898-907. [CrossRef]

59. Shike, H.; Shimizu, C.; Lauth, X.; Burns, J.C. Organization and expression analysis of the zebrafish hepcidin gene, an antimicrobial peptide gene conserved among vertebrates. Dev. Comp. Immunol. 2004, 28, 747-754. [CrossRef]

60. Hirono, I.; Hwang, J.-Y.; Ono, Y.; Kurobe, T.; Ohira, T.; Nozaki, R.; Aoki, T. Two different types of hepcidins from the Japanese flounder Paralichthys olivaceus. FEBS J. 2005, 272, 5257-5264. [CrossRef] 
61. Hocquellet, A.; Odaert, B.; Cabanne, C.; Noubhani, A.; Dieryck, W.; Joucla, G.; Le Senechal, C.; Milenkov, M.; Chaignepain, S.; Schmitter, J.-M.; et al. Structure-activity relationship of human liver-expressed antimicrobial peptide 2. Peptides 2010, 31, 58-66. [CrossRef] [PubMed]

62. Andersson, M.; Curstedt, T.; Jörnvall, H.; Johansson, J. An amphipathic helical motif common to tumourolytic polypeptide NK-lysin and pulmonary surfactant polypeptide SP-B. FEBS Lett. 1995, 362, 328-332. [CrossRef]

63. Anderson, D.H.; Sawaya, M.R.; Cascio, D.; Ernst, W.; Modlin, R.; Krensky, A.; Eisenberg, D. Granulysin crystal structure and a structure-derived lytic mechanism. J. Mol. Biol. 2003, 325, 355-365. [CrossRef]

64. Liepinsh, E.; Andersson, M.; Ruysschaert, J.M.; Otting, G. Saposin fold revealed by the NMR structure of NK-lysin. Nat. Struct. Biol. 1997, 4, 793-795. [CrossRef] [PubMed]

65. Zatylny-Gaudin, C.; Cornet, V.; Leduc, A.; Zanuttini, B.; Corre, E.; Le Corguillé, G.; Bernay, B.; Garderes, J.; Kraut, A.; Couté, Y.; et al. Neuropeptidome of the Cephalopod Sepia officinalis: Identification, Tissue Mapping, and Expression Pattern of Neuropeptides and Neurohormones during Egg Laying. J. Proteome Res. 2016, 15, 48-67. [CrossRef] [PubMed]

66. Chen, Y.; Gong, Q.; Song, M.; Lai, J.; Sun, J.; Liu, Y. Identification and characterization of three novel antimicrobial peptides from Acipenser dabryanus. Fish Shellfish Immunol. 2019, 88, 207-216. [CrossRef]

67. Rietschel, B.; Baeumlisberger, D.; Arrey, T.N.; Bornemann, S.; Rohmer, M.; Schuerken, M.; Karas, M.; Meyer, B. The Benefit of Combining nLC-MALDI-Orbitrap MS Data with nLC-MALDI-TOF/TOF Data for Proteomic Analyses Employing Elastase. J. Proteome Res. 2009, 8, 5317-5324. [CrossRef]

68. Bahar, A.; Ren, D. Antimicrobial Peptides. Pharmaceuticals 2013, 6, 1543-1575. [CrossRef]

69. Menanteau-Ledouble, S.; Kumar, G.; Saleh, M.; El-Matbouli, M. Aeromonas salmonicida: Updates on an old acquaintance. Dis. Aquat. Organ. 2016, 120, 49-68. [CrossRef] [PubMed]

70. King, W.L.; Jenkins, C.; Seymour, J.R.; Labbate, M. Oyster disease in a changing environment: Decrypting the link between pathogen, microbiome and environment. Mar. Environ. Res. 2019, 143, 124-140. [CrossRef]

71. Yin, L.M.; Edwards, M.A.; Li, J.; Yip, C.M.; Deber, C.M. Roles of Hydrophobicity and Charge Distribution of Cationic Antimicrobial Peptides in Peptide-Membrane Interactions. J. Biol. Chem. 2012, 287, 7738-7745. [CrossRef] [PubMed]

72. Dathe, M.; Wieprecht, T.; Nikolenko, H.; Handel, L.; Maloy, W.L.; MacDonald, D.L.; Beyermann, M.; Bienert, M. Hydrophobicity, hydrophobic moment and angle subtended by charged residues modulate antibacterial and haemolytic activity of amphipathic helical peptides. FEBS Lett. 1997, 403, 208-212. [CrossRef]

73. Myers, J.K.; Nick Pace, C.; Martin Scholtz, J. Trifluoroethanol effects on helix propensity and electrostatic interactions in the helical peptide from ribonuclease T 1. Protein Sci. 1998, 7, 383-388. [CrossRef] [PubMed]

74. Roccatano, D.; Colombo, G.; Fioroni, M.; Mark, A.E. Mechanism by which 2,2,2-trifluoroethanol/water mixtures stabilize secondary-structure formation in peptides: A molecular dynamics study. Proc. Natl. Acad. Sci. 2002, 99, 12179-12184. [CrossRef] [PubMed]

75. Niu, S.-F.; Jin, Y.; Xu, X.; Qiao, Y.; Wu, Y.; Mao, Y.; Su, Y.-Q.; Wang, J. Characterization of a novel piscidin-like antimicrobial peptide from Pseudosciaena crocea and its immune response to Cryptocaryon irritans. Fish Shellfish Immunol. 2013, 35, 513-524. [CrossRef] [PubMed]

76. Peng, K.-C.; Lee, S.-H.; Hour, A.-L.; Pan, C.-Y.; Lee, L.-H.; Chen, J.-Y. Five Different Piscidins from Nile Tilapia, Oreochromis niloticus: Analysis of Their Expressions and Biological Functions. PLoS One 2012, 7. [CrossRef] [PubMed]

77. Ruangsri, J.; Salger, S.A.; Caipang, C.M.A.; Kiron, V.; Fernandes, J.M.O. Differential expression and biological activity of two piscidin paralogues and a novel splice variant in Atlantic cod (Gadus morhua L.). Fish Shellfish Immunol. 2012, 32, 396-406. [CrossRef]

78. Hirsch, J.G. BACTERICIDAL ACTION OF HISTONE. J. Exp. Med. 1958, 108, 925-944. [CrossRef]

79. Barbour, A.B.; Allen, M.S.; Frazer, T.K.; Sherman, K.D. Evaluating the Potential Efficacy of Invasive Lionfish (Pterois volitans) Removals. PLoS One 2011, 6, e19666. [CrossRef]

80. Cornet, V.; Henry, J.; Corre, E.; Le Corguille, G.; Zanuttini, B.; Zatylny-Gaudin, C. Dual role of the cuttlefish salivary proteome in defense and predation. J. Proteomics 2014, 108, 209-222. [CrossRef]

81. Bolger, A.M.; Lohse, M.; Usadel, B. Trimmomatic: A flexible trimmer for Illumina sequence data. Bioinformatics 2014, 30, 2114-2120. [CrossRef]

82. Grabherr, M.G.; Haas, B.J.; Yassour, M.; Levin, J.Z.; Thompson, D.A.; Amit, I.; Adiconis, X.; Fan, L.; Raychowdhury, R.; Zeng, Q.; et al. Full-length transcriptome assembly from RNA-Seq data without a reference genome. Nat. Biotechnol. 2011, $29,644-652$. [CrossRef] [PubMed]

83. Haas, B.J.; Papanicolaou, A.; Yassour, M.; Grabherr, M.; Blood, P.D.; Bowden, J.; Couger, M.B.; Eccles, D.; Li, B.; Lieber, M.; et al. De novo transcript sequence reconstruction from RNA-seq using the Trinity platform for reference generation and analysis. Nat. Protoc. 2013, 8, 1494-1512. [CrossRef] [PubMed]

84. Petersen, T.N.; Brunak, S.; von Heijne, G.; Nielsen, H. SignalP 4.0: Discriminating signal peptides from transmembrane regions. Nat. Methods 2011, 8, 785-786. [CrossRef] [PubMed]

85. Krogh, A.; Larsson, B.; von Heijne, G.; Sonnhammer, E.L. Predicting transmembrane protein topology with a hidden markov model: Application to complete genomes-Edited by F. Cohen. J. Mol. Biol. 2001, 305, 567-580. [CrossRef] [PubMed]

86. Finn, R.D.; Bateman, A.; Clements, J.; Coggill, P.; Eberhardt, R.Y.; Eddy, S.R.; Heger, A.; Hetherington, K.; Holm, L.; Mistry, J.; et al. Pfam: The protein families database. Nucleic Acids Res. 2014, 42. [CrossRef] 
87. Houyvet, B.; Zanuttini, B.; Corre, E.; Le Corguillé, G.; Henry, J.; Zatylny-Gaudin, C. Design of antimicrobial peptides from a cuttlefish database. Amino Acids 2018, 50, 1573-1582. [CrossRef] [PubMed]

88. Benoist, L.; Houyvet, B.; Henry, J.; Corre, E.; Zanuttini, B.; Zatylny-Gaudin, C. In-Depth In Silico Search for Cuttlefish (Sepia officinalis) Antimicrobial Peptides Following Bacterial Challenge of Haemocytes. Mar. Drugs 2020, 18, 439. [CrossRef] [PubMed]

89. Syvitski, R.T.; Burton, I.; Mattatall, N.R.; Douglas, S.E.; Jakeman, D.L. Structural Characterization of the Antimicrobial Peptide Pleurocidin from Winter Flounder. Biochemistry 2005, 44, 7282-7293. [CrossRef]

90. Yang, J.; Lu, X.-J.; Chai, F.-C.; Chen, J. Molecular characterization and functional analysis of a piscidin gene in large yellow croaker (Larimichthys crocea). Sci. Press Zool. Res. 2016, 37, 347-355. [CrossRef]

91. Langmead, B.; Salzberg, S.L. Fast gapped-read alignment with Bowtie 2. Nat. Methods 2012, 9, 357-359. [CrossRef]

92. Li, B.; Dewey, C.N. RSEM: Accurate transcript quantification from RNA-Seq data with or without a reference genome. BMC Bioinformatics 2011, 12, 323. [CrossRef] [PubMed]

93. Wang, G.; Li, X.; Wang, Z. APD3: The antimicrobial peptide database as a tool for research and education. Nucleic Acids Res. 2016, 44. [CrossRef] [PubMed]

94. Gautier, R.; Douguet, D.; Antonny, B.; Drin, G. HELIQUEST: A web server to screen sequences with specific -helical properties. Bioinformatics 2008, 24, 2101-2102. [CrossRef]

95. Hetru, C.; Bulet, P. Strategies for the isolation and characterization of antimicrobial peptides of invertebrates. Methods Mol. Biol. 1997, 78, 35-49. [CrossRef] [PubMed]

96. Duval, E.; Zatylny, C.; Laurencin, M.; Baudy-Floc'h, M.; Henry, J. KKKKPLFGLFFGLF: A cationic peptide designed to exert antibacterial activity. Peptides 2009, 30, 1608-1612. [CrossRef] [PubMed]

97. Micsonai, A.; Wien, F.; Kernya, L.; Lee, Y.-H.; Goto, Y.; Réfrégiers, M.; Kardos, J. Accurate secondary structure prediction and fold recognition for circular dichroism spectroscopy. Proc. Natl. Acad. Sci. USA 2015, 112, E3095-E3103. [CrossRef] 